\title{
The Practical Synthesis of a Novel and Highly Potent Analog of Bryostatin
}

\author{
Paul A. Wender, ${ }^{*}$ Jeremy L. Baryza, Chad E. Bennett, F. Christopher Bi, Stacey E. Brenner, Michael
} O. Clarke, Joshua C. Horan, Cindy Kan, Emmanuel Lacôte, Blaise Lippa, Peter G. Nell, Tim M. Turner Department of Chemistry, Stanford University, Stanford, CA 94305-5080

\section{Supporting Information}

General methods. Air- and moisture-sensitive reactions were carried out in oven-dried glassware sealed with rubber septa under a positive pressure of dry nitrogen or argon from a manifold or balloon, unless otherwise indicated. Similarly sensitive liquids and solutions were transferred via syringe or stainless steel cannula. Reactions were stirred using Teflon-coated magnetic stir bars. Elevated temperatures were maintained using Thermowatch-controlled silicone oil baths. Organic solutions were concentrated using a Buchi rotary evaporator with a teflon seal vacuum pump. Tetrahydrofuran, diethyl ether, toluene and dicholoromethane were passed through an alumina drying column (Solv-Tek Inc.). Analytical TLC was performed with $0.25 \mathrm{~mm}$ silica gel $60 \mathrm{~F}$ plates with $254 \mathrm{~nm}$ fluorescent indicator from Merck. Plates were visualized by ultraviolet light and treatment with acidic $p$-anisaldehyde stain followed by gentle heating. Chromatographic purification of products was accomplished by flash chromatography, as described by Still and co-workers. ${ }^{1}$ Silica gel 60, 230-400 mesh was purchased from EM.

NMR spectra were measured on a Varian INOVA $500\left({ }^{1} \mathrm{H}\right.$ at $500 \mathrm{MHz},{ }^{13} \mathrm{C}$ at $125 \mathrm{MHz})$, Varian XL-400 $\left({ }^{1} \mathrm{H}\right.$ at $400 \mathrm{MHz},{ }^{13} \mathrm{C}$ at $\left.100 \mathrm{MHz}\right)$, Varian Gem-300 $\left({ }^{1} \mathrm{H}\right.$ at $300 \mathrm{MHz}$, ${ }^{13} \mathrm{C}$ at $\left.75 \mathrm{MHz}\right)$, or Varian $\mathrm{Gem}-200\left({ }^{1} \mathrm{H}\right.$ at $200 \mathrm{MHz},{ }^{13} \mathrm{C}$ at $\left.50 \mathrm{MHz}\right)$ magnetic resonance spectrometer. Data for ${ }^{1} \mathrm{H}$ NMR spectra are reported as follows: chemical shift $(\square \mathrm{ppm})$, integration, multiplicity $(\mathrm{s}=$ singlet, brs $=$ broad singlet, $\mathrm{d}=$ doublet, brd $=$ broad doublet, $\mathrm{t}=$ triplet, $\mathrm{q}=$ quartet, $\mathrm{dd}=$ doublet of doublets, $\mathrm{dt}=$ doublet of triplets, $\mathrm{ddd}=$ doublet of doublet of doublets, dddd $=$ doublet of doublet of doublet of doublets, $\mathrm{ddt}=$ doublet of doublet of triplets, $\mathrm{m}$ $=$ multiplet $)$, coupling constant $(\mathrm{Hz})$. Data for ${ }^{13} \mathrm{C}$ are reported in terms of chemical shift relative to residual solvent peak. Infrared spectra were recorded on a Perkin-Elmer 1600 Series Fourier transform spectrometer (FTIR) and are reported in wavenumbers $\left(\mathrm{cm}^{-1}\right)$. Elemental analyses $(\% \mathrm{C}, \% \mathrm{H})$ were determined by Desert Analytics, Tucson, Arizona. Reported atomic percentages are within error limits of $\pm 0.4 \%$. In instances where purity was not determined by elemental analysis, compounds displayed only one observable spot by TLC at the reported $\mathrm{R}_{\mathrm{f}}$. Highresolution mass spectra (HRMS) were recorded at the NIH regional mass spectrometry facility at the University of California, San Francisco. Reported mass values are with error limits of \pm 13 millimass units.

\footnotetext{
${ }^{1}$ Still, W. C.; Kahn, M.; Mitra, A. J. Org. Chem. 1978, 43, 2923.
} 


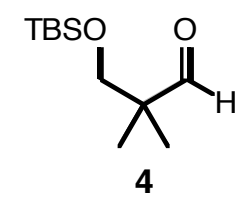

A 3-neck flask was charged with $\mathrm{NaH}(16 \mathrm{~g}, 60 \mathrm{wt} \%$ in mineral oil, $0.40 \mathrm{~mol})$. The $\mathrm{NaH}$ was washed with $\mathrm{Et}_{2} \mathrm{O}(3 \times 40 \mathrm{~mL})$. THF $(800 \mathrm{~mL})$ was added and the mixture stirred. To this suspension was added 2,2-dimethyl-1,3-propanediol (40 g, $0.39 \mathrm{~mol})$ in portions over $10 \mathrm{~min}$. The resulting thick slurry was stirred at $\mathrm{rt}$ for $1 \mathrm{~h}$. TBSCl $(60.5 \mathrm{~g}, 0.40 \mathrm{~mol})$ was added in one portion. The slurry thinned and was stirred at $\mathrm{rt}$ for $14 \mathrm{~h}$. The reaction was diluted with MTBE $(1.0 \mathrm{~L})$ and washed with $10 \%$ aq. $\mathrm{K}_{2} \mathrm{CO}_{3}(700 \mathrm{~mL}, 300 \mathrm{~mL})$ and brine $(500 \mathrm{~mL})$. The organic layer was dried over $\mathrm{Na}_{2} \mathrm{SO}_{4}$, filtered, and concentrated under reduced pressure to yield a viscous liquid $(88.4 \mathrm{~g})$ that was used without further purification.

A solution of this crude liquid (40 g, ca $0.18 \mathrm{~mol}$ ) was stirred in $\mathrm{CH}_{2} \mathrm{Cl}_{2}(900 \mathrm{~mL})$ and cooled in an ice bath to $4^{\circ} \mathrm{C}$. To this solution was added $\mathrm{NEt}_{3}(76 \mathrm{~mL}, 0.54 \mathrm{~mol})$. A slurry of $\mathrm{SO}_{3} \cdot \operatorname{pyr}(44 \mathrm{~g}, 0.27 \mathrm{~mol})$ in DMSO $(100 \mathrm{~mL})$ was added in two portions 5 min apart to keep the internal temperature lower than $10^{\circ} \mathrm{C}$. The reaction was stirred for $2.5 \mathrm{~h}$ and the ice bath was removed. Stirring was continued for $6.5 \mathrm{~h}$ and another portion of $\mathrm{SO}_{3} \cdot \operatorname{pyr}(10 \mathrm{~g}, 63 \mathrm{mmol})$ was added as a solid. The reaction was stirred for $9 \mathrm{~h}$ and diluted with $\mathrm{CH}_{2} \mathrm{Cl}_{2}(1.0 \mathrm{~L})$. The resulting solution was washed with $1 \mathrm{~N} \mathrm{HCl}(2 \times 500 \mathrm{~mL})$, saturated $\mathrm{NaHCO}_{3}(500 \mathrm{~mL})$, and brine $(500$ $\mathrm{mL}$ ). The resulting organic layer was dried over $\mathrm{Na}_{2} \mathrm{SO}_{4}$, filtered, and concentrated under reduced pressure to 4 (39.8 g) as an orange liquid that was used without further purification. ${ }^{2}$

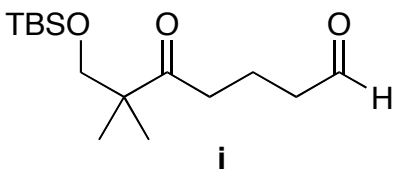

A solution of 4-chloro-1-butanol $(23 \mathrm{~mL}, 0.23 \mathrm{~mol})$ in THF $(230 \mathrm{~mL})$ was cooled to $-78^{\circ} \mathrm{C}$. A solution of $\mathrm{MeMgCl}(77 \mathrm{~mL}, 3.0 \mathrm{M}$ in THF, $0.23 \mathrm{~mol})$ was added dropwise via addition funnel over $30 \mathrm{~min}$ to keep the internal temperature lower than $-60^{\circ} \mathrm{C}$. The reaction was gradually warmed to $-10^{\circ} \mathrm{C}$ and $\mathrm{Mg}^{0}(6.04 \mathrm{~g}, 0.251 \mathrm{~mol})$ was added, followed by $\mathrm{BrCH}_{2} \mathrm{CH}_{2} \mathrm{Br}$ $(0.1 \mathrm{~mL})$. The reaction was heated to reflux for $14.5 \mathrm{~h}$. The hot bath was removed. THF (220 $\mathrm{mL}$ ) was added, and the reaction was cooled to $-78{ }^{\circ} \mathrm{C}$. A solution of 4 (39 $\left.\mathrm{g}, \mathrm{ca} 0.18 \mathrm{~mol}\right)$ in THF $(100 \mathrm{~mL})$ was added dropwise via addition funnel over $40 \mathrm{~min}$ to keep the internal temperature lower than $-60^{\circ} \mathrm{C}$. The reaction was stirred for $30 \mathrm{~min}$ at $-78^{\circ} \mathrm{C}$ and the cold bath was then removed. MTBE $(500 \mathrm{~mL})$ was added when the reaction reached $-30^{\circ} \mathrm{C}$, followed by aq. citric acid $\left(87 \mathrm{~g}, 0.41 \mathrm{~mol}\right.$ in $\left.500 \mathrm{~mL} \mathrm{H}_{2} \mathrm{O}\right)$. The organic layer was collected and the aqueous layer was extracted with MTBE $(200 \mathrm{~mL})$. The combined organic layers were washed with brine ( $2 \times 400 \mathrm{~mL}$ ), dried over $\mathrm{Na}_{2} \mathrm{SO}_{4}$, filtered, and concentrated under reduced pressure to a light orange oil. The oil was dissolved in EtOAc and filtered through silica. The filtrate was concentrated under reduced pressure to yield a light yellow oil $(49.7 \mathrm{~g})$ which was used without further purification.

To a solution of $\mathrm{CH}_{2} \mathrm{Cl}_{2}(800 \mathrm{~mL})$ was added $(\mathrm{COCl})_{2}(46.9 \mathrm{~mL}, 0.537 \mathrm{~mol})$ and the resulting solution cooled to $-78^{\circ} \mathrm{C}$. DMSO $(75.8 \mathrm{~mL}, 1.07 \mathrm{~mol})$ was added dropwise via addition funnel over $15 \mathrm{~min}$ to keep the internal temperature lower than $-60^{\circ} \mathrm{C}$. The resulting solution was stirred for $10 \mathrm{~min}$. A solution of the crude oil from the previous step $(49.7 \mathrm{~g}, \mathrm{ca} 0.179 \mathrm{~mol})$ in $\mathrm{CH}_{2} \mathrm{Cl}_{2}(150 \mathrm{~mL})$ was added dropwise via addition funnel over $25 \mathrm{~min}$ to keep the internal temperature lower than $-70^{\circ} \mathrm{C}$. The resulting mixture was stirred for $1 \mathrm{~h}$ at $-78^{\circ} \mathrm{C}$ and $\mathrm{NEt}_{3}(250$

\footnotetext{
${ }^{2}$ Richter, F.; Bauer, M.; Perez, C.; Maichle-Mössmer, C.; Maier, M. E. J. Org. Chem. 2002, 67, 24742480 .
} 
$\mathrm{mL}, 1.79 \mathrm{~mol}$ ) was added dropwise via addition funnel over $15 \mathrm{~min}$ to keep the internal temperature lower than $-60^{\circ} \mathrm{C}$. The cold bath was removed and the reaction was allowed to warm to $-30^{\circ} \mathrm{C}$ and then poured into a mixture of $\mathrm{H}_{2} \mathrm{O}(500 \mathrm{~mL})$ and $\mathrm{CH}_{2} \mathrm{Cl}_{2}(800 \mathrm{~mL})$. The resulting organic layer was collected and washed with $\mathrm{H}_{2} \mathrm{O}(500 \mathrm{~mL})$, saturated $\mathrm{NH}_{4} \mathrm{Cl}(2 \times 400 \mathrm{~mL})$, saturated $\mathrm{NaHCO}_{3}(500 \mathrm{~mL})$, and brine $(500 \mathrm{~mL})$. The organic layer was then dried over $\mathrm{Na}_{2} \mathrm{SO}_{4}$, filtered, and concentrated under reduced pressure to a dark oil. Purification by column chromatography (silica gel, 19:1 $\rightarrow$ 9:1 petroleum ether:/EtOAc) yielded $\mathbf{i}(27.81 \mathrm{~g}, 54 \%$ based on 2,2-dimethyl-1,3-propanediol) as a straw yellow liquid. i: $\mathbf{R}_{f}$ (petroleum ether/EtOAc 9:1) = 0.34; IR (film) 2956, 2931, 2896, 2858, 2715, 1727, 1707, 1472, 1409, 1392, 1363, 1257, 1187, 1094, 1044, $1007 \mathrm{~cm}^{-1}$; ${ }^{1} \mathrm{H}$ NMR $\left(300 \mathrm{MHz}, \mathrm{CDCl}_{3}\right) \square=0.02(6 \mathrm{H}, \mathrm{s}), 0.86(9 \mathrm{H}, \mathrm{s}), 1.08(6 \mathrm{H}, \mathrm{s})$, $1.88(2 \mathrm{H}$, app q, $J=7.0 \mathrm{~Hz}), 2.45(2 \mathrm{H}, \mathrm{td}, J=7.1,1.5 \mathrm{~Hz}), 2.58(2 \mathrm{H}, \mathrm{t}, J=7.0 \mathrm{~Hz}), 3.55(2 \mathrm{H}, \mathrm{s})$, $9.75(1 \mathrm{H}, \mathrm{s}) ;{ }^{13} \mathrm{C}$ NMR $\left(75 \mathrm{MHz}, \mathrm{CDCl}_{3}\right) \square=-5.7,15.9,18.0,21.4,25.7,36.7,43.1,49.3,70.2$, 202.1, 214.0; HRMS Calcd for $\mathrm{C}_{15} \mathrm{H}_{30} \mathrm{O}_{3} \mathrm{Si}\left(\mathrm{M}^{+}+\mathrm{H}\right): 287.2034$. Found 287.2040.

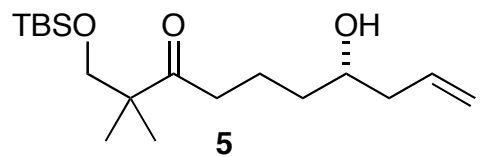

To a solution of R-BINOL (316 mg, $1.10 \mathrm{mmol})$ in $\mathrm{CH}_{2} \mathrm{Cl}_{2}(45 \mathrm{~mL})$ was added powdered $4 \AA$ MS $(4.2 \mathrm{~g})$ followed by $\mathrm{Ti}(\mathrm{O} i \mathrm{Pr})_{4}(0.16 \mathrm{~mL}, 0.55 \mathrm{mmol})$. The resulting orange mixture was heated to reflux for $1 \mathrm{~h}$ and then cooled in a water bath to rt. A solution of $\mathbf{i}(3.16 \mathrm{~g}, 11.0 \mathrm{mmol})$ in $\mathrm{CH}_{2} \mathrm{Cl}_{2}(5 \mathrm{~mL})$ was added, followed by $\mathrm{B}(\mathrm{OMe})_{3}(1.48 \mathrm{~mL}, 13.2 \mathrm{mmol})$ and $\mathrm{Bu}_{3} \mathrm{SnCH}_{2} \mathrm{CHCH}_{2}$ $(4.1 \mathrm{~mL}, 13 \mathrm{mmol})$. The resulting mixture was stirred at $\mathrm{rt}$ for $42 \mathrm{~h}$, then filtered through celite into saturated $\mathrm{NaHCO}_{3}(75 \mathrm{~mL})$ and EtOAc $(200 \mathrm{~mL})$. The resulting mixture was stirred for $1 \mathrm{~h}$. Petroleum ether $(200 \mathrm{~mL})$ was added and the resulting mixture filtered through celite. The organic layer was collected and washed with saturated $\mathrm{NaHSO}_{3}$, dried over $\mathrm{Na}_{2} \mathrm{SO}_{4}$, and concentrated under reduced pressure to a crude oil. The residue was purified by column chromatography (silica gel, 4:1 petroleum ether/EtOAc) to yield $5(2.81 \mathrm{~g}, 77 \%)$ as a yellow oil. 5: $\mathrm{R}_{f}$ (petroleum ether/EtOAc 9:1) = 0.13; IR (film) 3435 (br), 3077, 2955, 2930, 2858, 2743, $2711,1704,1642,1472,1392,1362,1257,1100,1006 \mathrm{~cm}^{-1} ;{ }^{1} \mathrm{H}$ NMR $\left(300 \mathrm{MHz}, \mathrm{CDCl}_{3}\right): \square=$ $0.02(6 \mathrm{H}, \mathrm{s}), 0.83(9 \mathrm{H}, \mathrm{s}), 1.06(6 \mathrm{H}, \mathrm{s}), 1.36-1.44(2 \mathrm{H}, \mathrm{m}), 1.55-1.69(2 \mathrm{H}, \mathrm{m}), 2.07-2.17(2 \mathrm{H}, \mathrm{m})$, $2.25(1 \mathrm{H}$, app dt, $J=13.8,5.5 \mathrm{~Hz}), 2.52(2 \mathrm{H}$, app td, $J=7.0,1.1 \mathrm{~Hz}), 3.53(2 \mathrm{H}, \mathrm{s}), 3.53-3.60(1 \mathrm{H}$, $\mathrm{m}), 5.06-5.11(2 \mathrm{H}, \mathrm{m}), 5.72-5.86(1 \mathrm{H}, \mathrm{m}) ;{ }^{13} \mathrm{C} \mathrm{NMR}\left(75 \mathrm{MHz}, \mathrm{CDCl}_{3}\right) \mathrm{C}=-5.7,19.3,21.5,25.8$, 36.3, 37.7, 41.8, 49.3, 70.2, 70.3, 117.9, 134.8, 215.0; Anal. calcd for $\mathrm{C}_{18} \mathrm{H}_{36} \mathrm{O}_{3} \mathrm{Si}: \mathrm{C}, 65.80 ; \mathrm{H}$, 11.04. Found: $\mathrm{C}, 65.83 ; \mathrm{H}, 11.31 .^{3}$

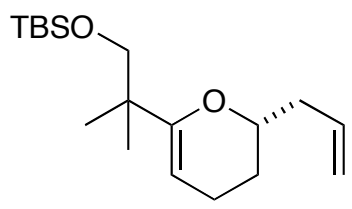

ii

To a solution of $5(28.8 \mathrm{~g}, 87.6 \mathrm{mmol})$ in $\mathrm{MePh}(500 \mathrm{~mL})$ was added bead $4 \AA$ MS $(50 \mathrm{~g})$ and $p \mathrm{TsOH} \cdot \mathrm{H}_{2} \mathrm{O}(1.66 \mathrm{~g}, 8.76 \mathrm{mmol})$. The mixture was stirred at $\mathrm{rt}$ for $18 \mathrm{~h}$ then filtered through basic alumina (Brockman grade I, basic, 150 mesh) and the alumina washed with petroleum ether. The filtrate was concentrated under reduced pressure to ii $(23.2 \mathrm{~g}, 85 \%)$ as a clear liquid. ii: $\mathrm{R}_{f}$ (petroleum ether) $=0.44$; IR (film) 3080, 2953, 2928, 2856, 1669, 1642, 1473, 1434, 1390,

\footnotetext{
${ }^{3}$ A reliable optical rotation for this compound could not be obtained due to its tendency to partially cyclize to the hemiketal.
} 
1359, 1288, 1254, 1215, $1088 \mathrm{~cm}^{-1}$; ${ }^{1} \mathrm{H}$ NMR (300 MHz, $\left.\mathrm{CDCl}_{3}\right) \square=0.01(6 \mathrm{H}, \mathrm{s}), 0.88(9 \mathrm{H}, \mathrm{s})$, $0.99(6 \mathrm{H}, \mathrm{s}), 1.40-1.53(1 \mathrm{H}, \mathrm{m}), 1.72-1.79(1 \mathrm{H}, \mathrm{m}), 1.91-2.12(2 \mathrm{H}, \mathrm{m}), 2.24(1 \mathrm{H}$, app dt, $J=13.8$, $6.8 \mathrm{~Hz}), 2.37(1 \mathrm{H}$, app dt, $J=14.0,7.0 \mathrm{~Hz}), 3.40(2 \mathrm{H}, \mathrm{s}), 3.70-3.78(1 \mathrm{H}, \mathrm{m}), 4.52(1 \mathrm{H}$, app t, $J=$ $3.5 \mathrm{~Hz}), 5.03-5.11(2 \mathrm{H}, \mathrm{m}), 5.80-5.94(1 \mathrm{H}, \mathrm{m}) ;{ }^{13} \mathrm{C} \mathrm{NMR}\left(75 \mathrm{MHz}, \mathrm{CDCl}_{3}\right) \square=-5.5,14.1,19.4$, 19.5, 22.6, 25.9, 39.6, 40.6, 41.5, 69.5, 74.4, 93.6, 116.6, 134.9, 158.3; Anal. calcd for $\mathrm{C}_{18} \mathrm{H}_{34} \mathrm{O}_{2} \mathrm{Si}: \mathrm{C}, 69.62 ; \mathrm{H}, 11.04$. Found: $\mathrm{C}, 69.64 ; \mathrm{H}, 11.16$; [ $]_{\mathrm{D}}{ }^{22}=+38.6^{\circ}\left(c 1.42, \mathrm{CH}_{2} \mathrm{Cl}_{2}\right)$.

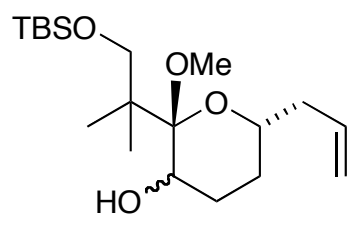

iii

A mixture of $80 \%$ MMPP (8.30 g, $13.4 \mathrm{mmol}), \mathrm{CH}_{2} \mathrm{Cl}_{2}(80 \mathrm{~mL}), \mathrm{MeOH}(40 \mathrm{~mL})$, and $\mathrm{NaHCO}_{3}(2.85 \mathrm{~g})$ was stirred in an ice bath. A solution of ii $(6.90 \mathrm{~g}, 22.4 \mathrm{mmol})$ in $\mathrm{CH}_{2} \mathrm{Cl}_{2}(10$ $\mathrm{mL}$ ) was added dropwise over $10 \mathrm{~min}$. The reaction was stirred for $10 \mathrm{~min}$, and then poured into $\mathrm{H}_{2} \mathrm{O}(100 \mathrm{~mL})$. The organic layer was collected and the aqueous layer was extracted with $\mathrm{CH}_{2} \mathrm{Cl}_{2}$ $(50 \mathrm{~mL})$. The combined organic layers were dried over $\mathrm{Na}_{2} \mathrm{SO}_{4}$, filtered, and concentrated under reduced pressure to a thick oil which was purified by column chromatography (silica gel, 19:1 $\rightarrow$ 9:1 petroleum ether/EtOAc) to provide iiia $(5.19 \mathrm{~g}, 64 \%)$ as a clear oil and iiib $(1.12 \mathrm{~g}, 14 \%)$ as a clear oil. iiia: $\mathrm{R}_{f}$ (petroleum ether/EtOAc 9:1) = 0.40; IR (film) 3585, 3467, 3408, 2935, 2857, 1643, 1472, 1440, 1255, 1091, $1044 \mathrm{~cm}^{-1}$; ${ }^{1} \mathrm{H}$ NMR $\left(300 \mathrm{MHz}, \mathrm{CDCl}_{3}\right) \quad \square=0.09(6 \mathrm{H}, \mathrm{s}), 0.92(9 \mathrm{H}$, s), $1.03(6 \mathrm{H}, \mathrm{s}), 1.20-1.36(1 \mathrm{H}, \mathrm{m}), 1.56-1.84(2 \mathrm{H}, \mathrm{m}), 2.16-2.26(2 \mathrm{H}, \mathrm{m}), 3.25(1 \mathrm{H}, \mathrm{d}, J=10.4$ $\mathrm{Hz}), 3.36(3 \mathrm{H}, \mathrm{s}), 3.35-3.50(1 \mathrm{H}, \mathrm{m}), 3.59-3.70(1 \mathrm{H}, \mathrm{m}), 3.82(1 \mathrm{H}, \mathrm{d}, J=10.4 \mathrm{~Hz}), 4.98-5.10(3 \mathrm{H}$, m), 5.80-5.95 $(1 \mathrm{H}, \mathrm{m}) ;{ }^{13} \mathrm{C}$ NMR $\left(300 \mathrm{MHz}, \mathrm{CDCl}_{3}\right) \square=-5.61,-5.56,18.3,22.4,22.8,25.8,27.5$, 30.1, 40.2, 45.2, 51.1, 68.7, 68.9, 70.7, 101.2, 116.6, 135.2; Anal. calcd for $\mathrm{C}_{19} \mathrm{H}_{38} \mathrm{O}_{4} \mathrm{Si}: \mathrm{C}, 63.64$; $\mathrm{H}, 10.68$. Found: $\mathrm{C}, 63.33 ; \mathrm{H}, 10.62 ;[\square]_{\mathrm{D}}^{21}=+39.44^{\circ}\left(c 1.35, \mathrm{CH}_{2} \mathrm{Cl}_{2}\right.$ ). iiib: $\mathrm{R}_{f}$ (petroleum ether/EtOAc 9:1) = 0.52; IR (film) 3479, 3368, 3077, 2950, 2390, 1643, 1471, 1254, $1060 \mathrm{~cm}^{-1}$; ${ }^{1} \mathrm{H}$ NMR $\left(300 \mathrm{MHz}, \mathrm{CDCl}_{3}\right)$ : $\square 0.09(6 \mathrm{H}, \mathrm{s}), 0.91(9 \mathrm{H}, \mathrm{s}), 0.97(3 \mathrm{H}, \mathrm{s}), 1.04(3 \mathrm{H}, \mathrm{s}), 1.16-1.35$ $(1 \mathrm{H}, \mathrm{m}), 1.60-1.95(3 \mathrm{H}, \mathrm{m}), 2.14-2.36(2 \mathrm{H}, \mathrm{m}), 3.34(3 \mathrm{H}, \mathrm{s}), 3.40(1 \mathrm{H}, \mathrm{d}, J=10.0 \mathrm{~Hz}), 3.57(1 \mathrm{H}$, $\mathrm{d}, J=10.1 \mathrm{~Hz}), 3.59-3.68(2 \mathrm{H}, \mathrm{m}), 4.97-5.12(2 \mathrm{H}, \mathrm{m}), 5.20-5.25(1 \mathrm{H}, \mathrm{m}), 5.80-5.98(1 \mathrm{H}, \mathrm{m}) ;{ }^{13} \mathrm{C}$ NMR $\left(300 \mathrm{MHz}, \mathrm{CDCl}_{3}\right) \mathrm{C}=[\mathbf{5} .74,-5.71,18.3,21.7,22.5,23.6,25.8,26.8,20.8,46.0,51.8$, 66.1, 69.9, 72.2, 102.2, 116.6, 135.0; HRMS Calcd for $\mathrm{C}_{19} \mathrm{H}_{38} \mathrm{O}_{4} \mathrm{Si}\left(\mathrm{M}^{+}\right)$: 356.2382. Found: $356.2395 ;[\square]_{\mathrm{D}}{ }^{21}=+25.48^{\circ}\left(c\right.$ 2.91, $\left.\mathrm{CH}_{2} \mathrm{Cl}_{2}\right)$.

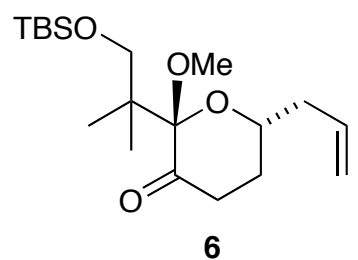

To a mixture of $4 \AA \mathrm{MS}(16.6 \mathrm{~g})$ and $\mathrm{CH}_{2} \mathrm{Cl}_{2}$ was added iiia $(10.18 \mathrm{~g}, 28.4 \mathrm{mmol})$ and NMO (6.65 g, $56.8 \mathrm{mmol})$. The reaction was stirred in an ice bath and TPAP (1.02 g, $2.84 \mathrm{mmol})$ was added in portions. Once the addition was complete, the ice bath was removed and the reaction was allowed to stir at $\mathrm{rt}$ for $20 \mathrm{~h}$. The resulting mixture was filtered through celite and the filtrate concentrated under reduced pressure. The residue was passed through a silica plug, eluting with $\mathrm{CH}_{2} \mathrm{Cl}_{2}$ and the filtrate rotovapped to a light colored oil $\mathbf{6}(7.91 \mathrm{~g}, 78 \%) \mathbf{6}: \mathrm{R}_{f}$ (petroleum ether/EtOAc 9:1) = 0.53; IR (film) 3078, 2955, 2930, 2893, 2858, 1726, 1644, 1472, 1464, 1446, 1406, 1393, 1361, 1302, 1254, 1188, 1117, 1089, 1054, $1006 \mathrm{~cm}^{-1}$; ${ }^{1} \mathrm{H}$ NMR (300 
$\left.\mathrm{MHz}, \mathrm{CDCl}_{3}\right) \square=0.02(6 \mathrm{H}, \mathrm{s}), 0.87(9 \mathrm{H}, \mathrm{s}), 0.93(3 \mathrm{H}, \mathrm{s}), 1.02(3 \mathrm{H}, \mathrm{s}), 1.86-2.05(2 \mathrm{H}, \mathrm{m}), 2.47-$ $2.27(3 \mathrm{H}, \mathrm{m}), 2.67(1 \mathrm{H}, \mathrm{ddd}, J=18.1,6.4,4.1 \mathrm{~Hz}), 3.27(3 \mathrm{H}, \mathrm{s}), 3.32(1 \mathrm{H}, \mathrm{d}, J=10.0 \mathrm{~Hz}), 3.68$ $(1 \mathrm{H}, \mathrm{d}, J=10.0 \mathrm{~Hz}), 3.89-3.97(1 \mathrm{H}, \mathrm{m}), 5.09-5.16(2 \mathrm{H}, \mathrm{m}), 5.84-5.98(1 \mathrm{H}, \mathrm{m}) ;{ }^{13} \mathrm{C}$ NMR $(75$ $\left.\mathrm{MHz}, \mathrm{CDCl}_{3}\right) \square=-5.6,-5.5,18.5,19.8,20.1,25.9,28.2,37.6,40.3,45.8,51.8,68.2,73.1,117.7$, 134.0; HRMS Calcd for $\mathrm{C}_{19} \mathrm{H}_{36} \mathrm{O}_{4} \mathrm{Si}\left(\mathrm{M}^{+}\right)$: 356.2383. Found: 356.2378. [D] ${ }_{\mathrm{D}}^{24}=-5.21^{\circ}$ (c 1.76, $\mathrm{CH}_{2} \mathrm{Cl}_{2}$ ).

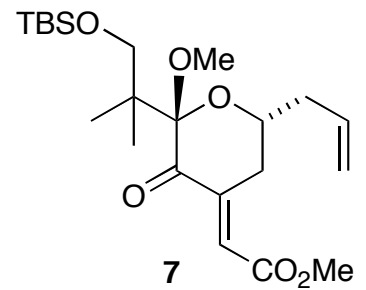

To a solution of $6(1.72 \mathrm{~g}$, $4.82 \mathrm{mmol})$ in $\mathrm{MeOH}(50 \mathrm{~mL})$ was added $\mathrm{K}_{2} \mathrm{CO}_{3}(3.66 \mathrm{~g}, 26.5$ $\mathrm{mmol})$ and a solution of methyl glyoxylate $(14.2 \mathrm{~mL}, \sim 1.7 \mathrm{M}, 24 \mathrm{mmol})$ in THF. The resulting mixture was stirred at $\mathrm{rt}$ for $55 \mathrm{~min}$ and then poured into a mixture of saturated $\mathrm{NH}_{4} \mathrm{Cl}(200 \mathrm{~mL})$ and $\mathrm{Et}_{2} \mathrm{O}(100 \mathrm{~mL})$. The organic layer was collected and the aqueous layer was extracted with $\mathrm{Et}_{2} \mathrm{O}(100 \mathrm{~mL})$. The combined organic layers were dried over $\mathrm{MgSO}_{4}$, filtered, and concentrated under reduced pressure to an orange oil which was purified by column chromatography (silica gel, 19:1 petroleum ether/EtOAc) to yield $7(1.50 \mathrm{~g}, 72 \%)$ as a yellow oil which solidified on standing. 7: $\mathrm{R}_{f}$ (petroleum ether/EtOAc 9:1) = 0.53; IR (film) 3079, 2954, 2930, 2858, 1726, $1709,1632,1472,1435,1416,1393,1357,1253,1204,1179,1128,1087,1061,1006 \mathrm{~cm}^{-1} ;{ }^{1} \mathrm{H}$ NMR (300 MHz, CDCl $) \square=-0.03(3 \mathrm{H}, \mathrm{s}),-0.02(3 \mathrm{H}, \mathrm{s}), 0.83(9 \mathrm{H}, \mathrm{s}), 0.91(3 \mathrm{H}, \mathrm{s}), 0.99(3 \mathrm{H}, \mathrm{s})$, $2.44(2 \mathrm{H}$, app t, $J=6.3 \mathrm{~Hz}), 2.76(1 \mathrm{H}, \mathrm{ddd}, J=17.8,12.4,3.2 \mathrm{~Hz}), 3.27(3 \mathrm{H}, \mathrm{s}), 3.30(1 \mathrm{H}, \mathrm{d}, J=$ $10.0 \mathrm{~Hz}), 3.46(1 \mathrm{H}, \mathrm{d}, J=17.8 \mathrm{~Hz}), 3.66(1 \mathrm{H}, \mathrm{d}, J=10.0 \mathrm{~Hz}), 3.76(3 \mathrm{H}, \mathrm{s}), 3.99(1 \mathrm{H}$, app dtd, $J=$ 11.4, 5.7, $1.7 \mathrm{~Hz}), 5.13-5.20(2 \mathrm{H}, \mathrm{m}), 5.86-6.00(1 \mathrm{H}, \mathrm{m}), 6.65-6.66(1 \mathrm{H}, \mathrm{m}) ;{ }^{13} \mathrm{C}$ NMR $(75 \mathrm{MHz}$, $\left.\mathrm{CDCl}_{3}\right) \square=-5.7,-5.6,18.5,19.5,19.9,25.9,34.2,39.8,46.4,51.7,51.9,68.1,72.0,103.9,118.3$, 122.6, 133.3, 147.5, 166.3, 196.1; Anal. Calcd for $\mathrm{C}_{22} \mathrm{H}_{38} \mathrm{O}_{6} \mathrm{Si}$ : C, 61.94; H, 8.98. Found: C, 62.32; H, 8.99; [D] $]_{\mathrm{D}}^{22}=-72.2^{\circ}\left(c 1.07, \mathrm{CH}_{2} \mathrm{Cl}_{2}\right)$.

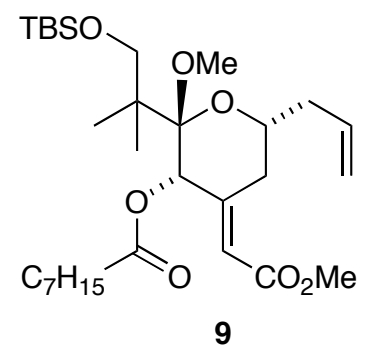

To a bright yellow solution of $7(3.29 \mathrm{~g}, 7.71 \mathrm{mmol})$ in $\mathrm{MeOH}(130 \mathrm{~mL})$ was added $\mathrm{CeCl}_{3} \cdot 7 \mathrm{H}_{2} \mathrm{O}(1.44 \mathrm{~g}, 3.86 \mathrm{mmol})$. The mixture was stirred until all solids were dissolved and then cooled to $-30^{\circ} \mathrm{C}$ for $15 \mathrm{~min}$. To this solution was added $\mathrm{NaBH}_{4}(0.58 \mathrm{~g}, 15 \mathrm{mmol})$ in one portion. The reaction was stirred for 5 min whereupon the color disappeared. The mixture was loaded directly onto a silica column and eluted with 15\% EtOAc in petroleum ether. Fractions containing product were washed with $\mathrm{H}_{2} \mathrm{O}(2 \mathrm{x})$ and brine $(3 \mathrm{x})$. The resulting organic layer was dried over $\mathrm{Na}_{2} \mathrm{SO}_{4}$, filtered, and concentrated under reduced pressure to provide crude oil 8 .

Crude 8 was dissolved in $\mathrm{CH}_{2} \mathrm{Cl}_{2}(75 \mathrm{~mL})$. DMAP (1.41 g, $\left.11.5 \mathrm{mmol}\right)$ and octanoic acid $(1.83 \mathrm{~mL}, 11.5 \mathrm{mmol})$ were added, followed by DIC $(1.81 \mathrm{~mL}, 11.6 \mathrm{mmol})$. The resulting mixture was stirred at $\mathrm{rt}$ for $20 \mathrm{~h}$. To the reaction was added saturated $\mathrm{NaHCO}_{3}$ and EtOAc. The resulting mixture was stirred for $5 \mathrm{~min}$ and then additional EtOAc and brine were added. The resulting organic layer was collected and the aqueous layer extracted with EtOAc. The combined 
organic layers were dried over $\mathrm{Na}_{2} \mathrm{SO}_{4}$, filtered, and concentrated under reduced pressure. The residue was purified by column chromatography (silica gel, 5:95 EtOAc/petroleum ether) to yield $9(3.98 \mathrm{~g}, 93 \%)$ as a pale yellow oil. 9: $\mathrm{R}_{f}$ (pentane/EtOAc 9:1) = 0.62; IR (film) 2955, 2930, 2857, 1747, 1722, 1667, 1155, $1082 \mathrm{~cm}^{-1} ;{ }^{1} \mathrm{H}$ NMR (300 MHz, $\left.\mathrm{CDCl}_{3}\right) \square=0.01(6 \mathrm{H}, \mathrm{s}), 0.80-$ $0.90(12 \mathrm{H}, \mathrm{m}), 0.96(3 \mathrm{H}, \mathrm{s}), 1.00(3 \mathrm{H}, \mathrm{s}), 1.20-1.38(10 \mathrm{H}, \mathrm{m}), 1.56-1.72(1 \mathrm{H}, \mathrm{m}), 2.24-2.46(4 \mathrm{H}$, $\mathrm{m}), 3.30(3 \mathrm{H}, \mathrm{s}), 3.43(1 \mathrm{H}, \mathrm{d}, J=15.9 \mathrm{~Hz}), 3.54(2 \mathrm{H}, \mathrm{dd}, J,=18.9,9.3 \mathrm{~Hz}), 3.68(3 \mathrm{H}, \mathrm{s}), 3.87-$ $3.91(1 \mathrm{H}, \mathrm{m}), 5.09-5.16(2 \mathrm{H}, \mathrm{m}), 5.53(1 \mathrm{H}, \mathrm{s}), 5.80-5.98(1 \mathrm{H}, \mathrm{m}), 5.88(1 \mathrm{H}, \mathrm{s}) ;{ }^{13} \mathrm{C}$ NMR $(300$ $\left.\mathrm{MHz}, \mathrm{CDCl}_{3}\right) \square=-5.4,14.0,18.4,20.5,20.6,22.6,24.7,25.9,28.9,29.0,31.6,32.1,34.5,40.0$, 47.0, 51.1, 67.3, 71.0, 72.1, 103.0, 116.6, 117.7, 133.8, 153.1, 166.6, 171.9; HRMS Calcd for $\mathrm{C}_{30} \mathrm{H}_{54} \mathrm{O}_{7} \mathrm{Si}\left(\mathrm{M}^{+}\right): 577.3517$. Found 577.3537; [ []$_{\mathrm{D}}{ }^{21}=-11.3\left(c 1.56, \mathrm{CH}_{2} \mathrm{Cl}_{2}\right)$

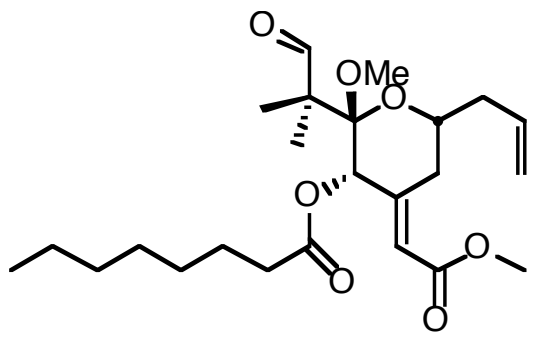

10

To a solution of TBS ether $9(30 \mathrm{mg}, 0.054 \mathrm{mmol})$ in THF $(0.55 \mathrm{~mL})$ at rt was added $3 \mathrm{HFEt}_{3} \mathrm{~N}(90 \square \mathrm{L}, 0.54 \mathrm{mmol})$. The reaction mixture was stirred for $24 \mathrm{~h}$ and then diluted with diethyl ether $(5 \mathrm{~mL})$. The organic phase was washed with saturated $\mathrm{NaHCO}_{3}(2 \times 3 \mathrm{~mL})$ and brine $(2 \times 3 \mathrm{~mL})$, dried over $\mathrm{Na}_{2} \mathrm{SO}_{4}$, and flashed through a plug of silica. The residue obtained after evaporation of solvent was carried forward without further purification.

To a solution of the deprotected alcohol in $\mathrm{CH}_{2} \mathrm{Cl}_{2}(1.5 \mathrm{~mL})$ and $\mathrm{MeCN}(2.1 \mathrm{~mL})$, at $\mathrm{rt}$, was added $\mathrm{NaHCO}_{3}(9.1 \mathrm{mg}, 0.11 \mathrm{mmol})$. The mixture was cooled to $0^{\circ} \mathrm{C}$ and Dess-Martin Periodinane $(52 \mathrm{mg}, 0.122 \mathrm{mmol})$ was added. The reaction mixture was stirred at $0^{\circ} \mathrm{C}$ for $1 \mathrm{~h}$. The reaction was quenched with $3 \mathrm{~mL}$ of a $1: 1$ solution of saturated $\mathrm{NaHCO}_{3}$ and saturated $\mathrm{Na}_{2} \mathrm{~S}_{2} \mathrm{O}_{3}$ and was stirred vigorously until the organic layer was no longer cloudy. The quenched reaction mixture was then poured into a separatory funnel. The aqueous layer was extracted with $\mathrm{CH}_{2} \mathrm{Cl}_{2}(3 \times 3 \mathrm{~mL})$. The organic layers were combined, dried over $\mathrm{Na}_{2} \mathrm{SO}_{4}$, filtered, and concentrated. Purification via column chromatography (silica gel, 95:5 petroleum ether/EtOAc) revealed pure aldehyde $\mathbf{1 0}\left(20 \mathrm{mg}, 86 \%\right.$ over 2 steps) as a yellow oil. 10: $\mathrm{R}_{f}$ (hexane/EtOAc $4: 1)=0.49$; IR (film) 2930, 2857, 1750, 1723, 1668, 1160, $1048 \mathrm{~cm}^{-1} ;{ }^{1} \mathrm{H}$ NMR $(300 \mathrm{MHz}$, $\left.\mathrm{CDCl}_{3}\right) \square=0.86(3 \mathrm{H}, \mathrm{t}, J=6.3 \mathrm{~Hz}$, octanoate Me), $1.00(3 \mathrm{H}, \mathrm{s}, \mathrm{C} 18 \mathrm{Me}), 1.16(3 \mathrm{H}, \mathrm{s}, \mathrm{C} 18 \mathrm{Me})$, $1.18-1.31(10 \mathrm{H}, \mathrm{m}), 1.46-1.60(2 \mathrm{H}, \mathrm{m}), 2.18(2 \mathrm{H}, \mathrm{t}, J=7.4 \mathrm{~Hz}), 2.43(2 \mathrm{H}, \mathrm{t}, J=6.6 \mathrm{~Hz}), 3.39$ $(3 \mathrm{H}, \mathrm{s}), 3.66(1 \mathrm{H}, \mathrm{d}, J=18.9 \mathrm{~Hz}), 3.69(3 \mathrm{H}, \mathrm{s}), 3.74-3.84(1 \mathrm{H}, \mathrm{m}), 5.13-5.20(2 \mathrm{H}, \mathrm{m}), 5.85-6.00$ $(1 \mathrm{H}, \mathrm{m}), 5.96(1 \mathrm{H}, \mathrm{s}), 9.71(1 \mathrm{H}, \mathrm{s}) ;{ }^{13} \mathrm{C} \mathrm{NMR}\left(75 \mathrm{MHz}, \mathrm{CDCl}_{3}\right) \square=14.1,16.3,19.1,22.6,24.3$, 28.9, 30.4, 31.6, 38.9, 40.0, 51.2, 51.4, 54.0, 71.5, 71.9, 102.2, 118.2, 119.8, 133.4, 150.3, 166.4, 171.7, 202.4; HRMS Calcd for $\mathrm{C}_{24} \mathrm{H}_{38} \mathrm{O}_{7}\left(\mathrm{M}^{+}\right)$: 461.2511. Found: 461.2515 ; $[\square]_{\mathrm{D}}{ }^{21.4}=-8.61^{\circ}(c$ 5.6, $\mathrm{CH}_{2} \mathrm{Cl}_{2}$ ). 


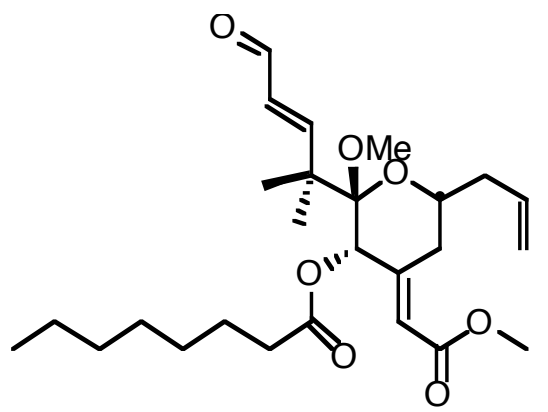

11

(Z)-1-bromo-2-ethoxyethylene (690 $\square \mathrm{L}, 6.5 \mathrm{mmol})$ was added to an oven-dried flask containing diethyl ether $(22 \mathrm{~mL})$. The solution was cooled to $-78^{\circ} \mathrm{C}$, and $t$-BuLi $(7.6 \mathrm{~mL}, 13$ mmol, $1.7 \mathrm{M}$ in pentane) was added, dropwise. The reaction was stirred, at $-78^{\circ} \mathrm{C}$, for $30 \mathrm{~min}$. $\mathrm{Me}_{2} \mathrm{Zn}$ (3.4 mL, $6.7 \mathrm{mmol}, 2.0 \mathrm{M}$ in toluene) was added, dropwise, and the reaction was stirred, at $-78^{\circ} \mathrm{C}$, for $30 \mathrm{~min}$. A $0.0001 \mathrm{M}$ solution of aldehyde $10(0.95 \mathrm{~g}, 2.2 \mathrm{mmol}$ dissolved in $22 \mathrm{~mL}$ $\mathrm{Et}_{2} \mathrm{O}$ ) was added dropwise, via syringe, and the reaction was stirred for $2 \mathrm{~h}$ at $-78^{\circ} \mathrm{C}$. The reaction was quenched with a $1.0 \mathrm{M}$ solution of $\mathrm{HCl}(40 \mathrm{~mL})$ and allowed to warm to $\mathrm{rt}$. The mixture was stirred vigorously for $19 \mathrm{~h}$ and was quenched with saturated $\mathrm{NaHCO}_{3}(60 \mathrm{~mL})$, diluted with EtOAc $(35 \mathrm{~mL})$ and $\mathrm{H}_{2} \mathrm{O}(35 \mathrm{~mL})$. The separated aqueous phase was extracted with EtOAc $(3 \times 60 \mathrm{~mL})$ and the combined organic phases were washed with brine $(1 \times 85 \mathrm{~mL})$. The organic layer was dried over $\mathrm{Na}_{2} \mathrm{SO}_{4}$, filtered, and concentrated in vacuo. Purification via column chromatography (silica gel, petroleum ether $\rightarrow 7 \% \rightarrow 10 \%$ EtOAc:petroleum ether) revealed pure enal 11 (905 mg, 90\%) as a nearly colorless oil. 11: $\mathrm{R}_{f}$ (hexane/EtOAc 4:1) $=0.46$; IR (film) 2930, 2360, 2343, 1746, 1721, 1689, 1436, 1382, 1259, 1225, 1156, 1104, $1044 \mathrm{~cm}^{-1}$; ${ }^{1} \mathrm{H}$ NMR $\left(300 \mathrm{MHz}, \mathrm{CDCl}_{3}\right) \square=0.86(3 \mathrm{H}, \mathrm{t}, J=6.3 \mathrm{~Hz}$, octanoate Me $), 1.13(3 \mathrm{H}, \mathrm{s}, \mathrm{C} 18 \mathrm{Me}), 1.17(3 \mathrm{H}, \mathrm{s}$, $\mathrm{C} 18 \mathrm{Me}), 1.23-1.31(10 \mathrm{H}, \mathrm{m}), 1.40(\mathrm{t}), 2.00-2.20(2 \mathrm{H}, \mathrm{m}) 2.24-2.36(\mathrm{~m}), 2.43(2 \mathrm{H}, \mathrm{t}), 3.34(3 \mathrm{H}$, s), 3.49-3.55 (1H, dd, $J=15.6 \mathrm{~Hz}, 1.8 \mathrm{~Hz}), 3.68(3 \mathrm{H}, \mathrm{s}), 3.81-3.86(1 \mathrm{H}, \mathrm{m}), 5.13(1 \mathrm{H}, \mathrm{m}), 5.20$ $(1 \mathrm{H}, \mathrm{m}), 5.37(1 \mathrm{H}, \mathrm{s}), 5.87(1 \mathrm{H}, \mathrm{s}), 5.87-5.95(1 \mathrm{H}, \mathrm{dd}, J=7.8 \mathrm{~Hz}, 16.1 \mathrm{~Hz}), 7.32(1 \mathrm{H}, \mathrm{d}, J=16.2$ $\mathrm{Hz}), 9.53(1 \mathrm{H}, \mathrm{d}, J=7.8 \mathrm{~Hz}) ;{ }^{13} \mathrm{C}$ NMR $\left(75 \mathrm{MHz}, \mathrm{CDCl}_{3}\right)$ : $\square=13.96,21.62,22.46,23.75,24.46$, 28.80, 28.84, 31.36, 31.51, 34.34, 39.92, 47.37, 51.18, 51.30, 71.36, 71.86, 97.85, 102.57, 117.97, 118.25, 126.75, 133.46, 151.56, 166.50, 167.19, 194.80; Anal. Calcd for $\mathrm{C}_{26} \mathrm{H}_{40} \mathrm{O}_{7}: \mathrm{C}, 67.22 ; \mathrm{H}$, 8.68. Found: C, 67.34; $\mathrm{H}, 8.48 ;[\square]_{\mathrm{D}}{ }^{24.2}=-31.79^{\circ}\left(c 0.47, \mathrm{CH}_{2} \mathrm{Cl}_{2}\right)$.

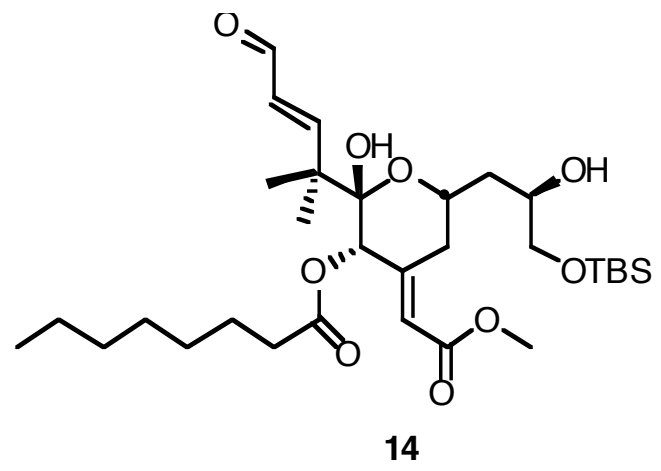

Preparation of stock solution: $\mathrm{K}_{2} \mathrm{OsO}_{2}(\mathrm{OH})_{4}(2.0 \mathrm{mg}, 0.005 \mathrm{mmol}),(\mathrm{DHQD}){ }_{2} \mathrm{PYR}(12.0$ $\mathrm{mg}, 0.014 \mathrm{mmol}), \mathrm{K}_{3} \mathrm{Fe}(\mathrm{CN})_{6}(1.34 \mathrm{~g}, 4.07 \mathrm{mmol})$, and $\mathrm{K}_{2} \mathrm{CO}_{3}(563 \mathrm{mg}, 4.07 \mathrm{mmol})$ were combined in a round-bottom flask, to which was added $\mathrm{H}_{2} \mathrm{O}(6.75 \mathrm{~mL})$ and $t \mathrm{BuOH}(6.75 \mathrm{~mL})$. The two-phase system was vigorously stirred at $\mathrm{rt}$ for $2 \mathrm{~h}$. Enal 11 (300 mg, $0.65 \mathrm{mmol}$ ) was cooled to $0^{\circ} \mathrm{C}$, and an aliquot $(6.4 \mathrm{~mL})$ of the stock solution was added. The yellow-orange 
colored reaction mixture was stirred at $0-4^{\circ} \mathrm{C}$ for $60 \mathrm{~h}$ (in cold room). After diluting with water $(50 \mathrm{~mL})$ the aqueous phase was extracted with ethyl acetate $(3 \times 250 \mathrm{~mL})$. The combined organic phases were dried over $\mathrm{MgSO}_{4}$, and then filtered. The solvents were removed in vacuo. Purification via column chromatography (silica gel, 1:9 hexane:ethyl acetate) yielded diol 12 (233 $\mathrm{mg}, 72 \%)$ as a 2.5:1 $\square: \square$ inseparable mixture of diastereomers.

Diol $12(10 \mathrm{mg}, 0.020 \mathrm{mmol})$ was taken up in a solution of $\mathrm{MeCN}: \mathrm{H}_{2} \mathrm{O}(960 \square \mathrm{L}, 240$ $\square \mathrm{L})$, and transferred to an oven-dried flask. $p \mathrm{TsOH} \cdot \mathrm{H}_{2} \mathrm{O}(38 \mathrm{mg}, 0.200 \mathrm{mmol})$ was added as $0.22 \mathrm{M}$ solution in $\mathrm{MeCN}: \mathrm{H}_{2} \mathrm{O}(730 \square \mathrm{L}, 180 \square \mathrm{L})$. The reaction was stirred overnight, at $\mathrm{rt}$, and then quenched with saturated $\mathrm{NaHCO}_{3}(6 \mathrm{~mL})$. The aqueous phase was extracted with EtOAc (3 x $2 \mathrm{~mL}$ ). The combined organic layers were dried over $\mathrm{Na}_{2} \mathrm{SO}_{4}$, filtered, and concentrated in vacuo. Crude product $\mathbf{1 3}$ was carried forward without further purification.

A $0.5 \mathrm{M}$ stock solution of 1:3 TBSCl:imidazole was prepared by dissolving TBSCl (754 $\mathrm{mg}, 5.0 \mathrm{mmol})$ and imidazole $(1.02 \mathrm{~g}, 15.0 \mathrm{mmol})$ in $\mathrm{CH}_{2} \mathrm{Cl}_{2}(10.0 \mathrm{~mL})$. A total of 9 eq. of this stock solution were added to a solution of $\mathbf{1 3}$ in $\mathrm{CH}_{2} \mathrm{Cl}_{2}(2.0 \mathrm{~mL})$, over the course of $6 \mathrm{~h}$ (added in 3 eq. aliquots, $2 \mathrm{~h}$ apart). Reaction was quenched with saturated $\mathrm{NH}_{4} \mathrm{Cl}(2 \mathrm{~mL})$ and the aqueous phase was extracted with EtOAc $(3 \times 2 \mathrm{~mL})$. The combined organic phases were dried over $\mathrm{Na}_{2} \mathrm{SO}_{4}$, filtered, and concentrated in vacuo. Purification via column chromatography (silica gel, 3:1 Hexanes/EtOAc) revealed pure 14 (5.6 mg, 47\% over 2 steps $)$. 14: $\mathrm{R}_{f} \quad($ EtOAc/pentane 4:6) = 0.38; IR (film) 3421, 2930, 2857, 1723, 1691, 1257, 1156, $1110 \mathrm{~cm}^{-1} ;{ }^{1} \mathrm{H}$ NMR (400 MHz, $\left.\mathrm{CDCl}_{3}\right) \mathrm{C}=0.10(6 \mathrm{H}, \mathrm{s}), 0.87(3 \mathrm{H}, \mathrm{t}, J=6.8 \mathrm{~Hz}), 0.92(9 \mathrm{H}, \mathrm{s}), 1.14(3 \mathrm{H}, \mathrm{s}), 1.15(3 \mathrm{H}, \mathrm{s}), 1.18-$ $1.32(10 \mathrm{H}, \mathrm{m}), 1.49(1 \mathrm{H}, \mathrm{t}, J=7.2 \mathrm{~Hz}), 1.66-1.74(1 \mathrm{H}, \mathrm{m}), 1.84-2.00(1 \mathrm{H}, \mathrm{m}), 1.98-2.15(3 \mathrm{H}, \mathrm{m})$, $3.49(1 \mathrm{H}, \mathrm{dd}, J=10.0,6.0 \mathrm{~Hz}), 3.66-3.76(1 \mathrm{H}, \mathrm{m}), 3.70(3 \mathrm{H}, \mathrm{s}), 3.82-4.00(2 \mathrm{H}, \mathrm{m}), 4.07(1 \mathrm{H}, \mathrm{t}, J$ $=6.6 \mathrm{~Hz}), 4.20(1 \mathrm{H}, \mathrm{t}, J=10.8 \mathrm{~Hz}), 5.13(1 \mathrm{H}, \mathrm{s}), 5.96(1 \mathrm{H}, \mathrm{dd}, J=16.0,7.7 \mathrm{~Hz}), 6.03(1 \mathrm{H}, \mathrm{s})$, $7.35(1 \mathrm{H}, \mathrm{d}, J=16.0 \mathrm{~Hz}), 9.57(1 \mathrm{H}, \mathrm{d}, J=7.7 \mathrm{~Hz}) ;{ }^{13} \mathrm{C}$ NMR $\left(100 \mathrm{MHz}, \mathrm{CDCl}_{3}\right) \square=-5.3,14.0$, 18.4, 20.0, 22.5, 23.1, 24.4, 25.9, 28.9, 28.9, 31.1, 31.6, 34.5, 39.0, 45.7, 51.3, 67.1, 67.2, 67.9, 72.6, 99.7, 120.7, 127.6, 150.1, 166.1, 171.7, 194.5; HRMS Calcd for $\mathrm{C}_{31} \mathrm{H}_{54} \mathrm{O}_{9} \mathrm{Si}\left(\mathrm{M}^{+}\right)$: 621.3445, Found: $621.3435 ;[\square]_{\mathrm{D}}^{26.6}=-27.24^{\circ}\left(c 1.04, \mathrm{CH}_{2} \mathrm{Cl}_{2}\right)$.

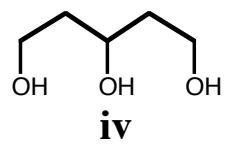

To a flask was added 1,6-heptadiene-4-ol (4.183 g, $37.3 \mathrm{mmol}$, Aldrich) and anhydrous $\mathrm{MeOH}\left(180 \mathrm{~mL}\right.$, JT Baker). The reaction flask was cooled to $-78^{\circ} \mathrm{C}$ and ozone was bubbled through the solution for 35 min until a deep blue color persisted. $\mathrm{N}_{2}$ was bubbled through the solution for 20 min to purge excess ozone. To the stirring solution at $-78^{\circ} \mathrm{C}$ was added $\mathrm{NaBH}_{4}$ $(11.3 \mathrm{~g}, 299 \mathrm{mmol})$. The mixture was allowed to stir for $12 \mathrm{~h}$ while it warmed to $\mathrm{rt}$ in the thawing bath. The reaction was acidified to $\mathrm{pH} 3$ with conc. $\mathrm{HCl}$ until a white precipitate formed. The solution was filtered to remove the precipitate and the filtrate was concentrated in vacuo. The residue was dissolved in $\mathrm{MeOH}(200 \mathrm{~mL})$ and concentrated in vacuo. This $\mathrm{MeOH}$ evaporation was repeated one additional time to ensure the removal of residual boron as $\mathrm{B}(\mathrm{OMe})_{3}$. The resulting orange residue was vacuum distilled to give iv $(4.02 \mathrm{~g}, 94 \%)$. iv: $\mathrm{R}_{f}$ (EtOH (200 prf.)/EtOAc 1:4) = 0.4; IR (film) 3338, 2944, 2888, 1421, $1061 \mathrm{~cm}^{-1} ;{ }^{1} \mathrm{H}$ NMR $\left(500 \mathrm{MHz}, \mathrm{D}_{2} \mathrm{O}\right)$ $=1.66(4 \mathrm{H}, \mathrm{m}), 3.64(4 \mathrm{H}, \mathrm{t}, J=6.5 \mathrm{~Hz}), 3.82(1 \mathrm{H}, \mathrm{m}, J=4 \mathrm{~Hz}) ;{ }^{13} \mathrm{C} \mathrm{NMR}\left(500 \mathrm{MHz}, \mathrm{CD}_{3} \mathrm{OD}\right) \square$ $=41.06,60.12$, 67.41; Anal. calcd for $\mathrm{C}_{5} \mathrm{H}_{12} \mathrm{O}_{3}: \mathrm{C}, 49.98 ; \mathrm{H}, 10.07$. Found: $\mathrm{C}, 50.05 ; \mathrm{H}, 10.29$. 


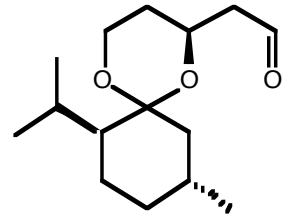

$16 \square$

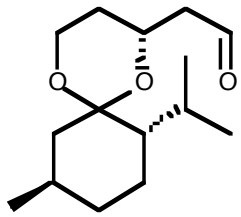

$16 \square$

To an oven dried, argon purged 1L round bottom flask, charged with a magnetic stir bar, was added iv $(8.40 \mathrm{~g}, 70 \mathrm{mmol})$ at $\mathrm{rt}$. To this was added (-)-menthone $(27.9 \mathrm{~mL}, 161 \mathrm{mmol}, \sim 5 \%$ isomenthone, Aldrich), $p \mathrm{TsOH} \bullet \mathrm{H}_{2} \mathrm{O}(658 \mathrm{mg}, 3.5 \mathrm{mmol}$, Aldrich), followed by diethyl ether (232 $\mathrm{mL})$. Triethyl orthoformate $(26 \mathrm{~mL}, 154 \mathrm{mmol}$, Aldrich) was then added followed by additional diethyl ether $(232 \mathrm{~mL})$. The reaction was stirred for $48 \mathrm{~h}$ at $\mathrm{rt}$ and then a mixture of $1 \mathrm{~N} \mathrm{NaOH}$ $(155 \mathrm{~mL})$ and EtOH $(50 \mathrm{~mL}, 200$ proof $)$ was added. The mixture was allowed to stir for an additional $24 \mathrm{~h}$. The reaction was extracted with $\mathrm{CH}_{2} \mathrm{Cl}_{2}(3 \times 100 \mathrm{~mL})$ and the organic layers were combined, dried over $\mathrm{MgSO}_{4}$ and concentrated. Purification by column chromatography (silica gel, 20:80 EtOAc/hexanes) gave a mixture of alcohols $(12.77 \mathrm{~g}, 71 \%$ ) as a yellow oil, which was taken directly into the next step.

A solution of DMSO $(3.41 \mathrm{~mL}, 48.25 \mathrm{mmol})$ in $\mathrm{CH}_{2} \mathrm{Cl}_{2}(12 \mathrm{~mL})$ at $-78^{\circ} \mathrm{C}$ was cannulated dropwise into a solution of oxalyl chloride $(3.35 \mathrm{~mL}, 38.6 \mathrm{mmol})$ in $\mathrm{CH}_{2} \mathrm{Cl}_{2}(77 \mathrm{~mL})$ at $-78^{\circ} \mathrm{C}$ under $\mathrm{N}_{2}$ and stirred for $20 \mathrm{~min}$. Crude alcohol (4.94 g, $\left.19.3 \mathrm{mmol}\right)$ in $\mathrm{CH}_{2} \mathrm{Cl}_{2}(39 \mathrm{~mL})$ at $-78^{\circ} \mathrm{C}$ was then slowly cannulated into the reaction mixture at $-78^{\circ} \mathrm{C}$ over $30 \mathrm{~min}$. The reaction was maintained at $-78^{\circ} \mathrm{C}$ with stirring for $2 \mathrm{~h}$ then $\mathrm{Et}_{3} \mathrm{~N}(18.83 \mathrm{~mL}, 135.1 \mathrm{mmol})$ was added dropwise via syringe over $5 \mathrm{~min}$. The reaction was transferred to a $0^{\circ} \mathrm{C}$ ice bath and allowed to warm to rt over $2 \mathrm{~h}$. The reaction was diluted with $4: 1$ petroleum ether $/ \mathrm{Et}_{2} \mathrm{O}(500 \mathrm{~mL})$ and extracted with saturated $\mathrm{NH}_{4} \mathrm{Cl}(3 \times 50 \mathrm{~mL})$ followed by brine $(1 \times 100 \mathrm{~mL})$. The organic phase was dried over $\mathrm{MgSO}_{4}$, filtered and concentrated. Purification by flash chromatography (silica gel, 4:1

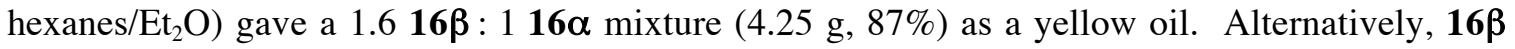
and $16 \square$ could be separated by flash chromatography (silica gel, 4:1 hexanes/Et ${ }_{2} \mathrm{O}$ ). For operational simplicity, the mixture of diastereomers can be taken directly into the next reaction if desired. 16 $\square: \mathrm{R}_{f}\left(\mathrm{Et}_{2} \mathrm{O} /\right.$ hexanes 2:8) = 0.33; IR (film) 2952, 2869, 1728, 1456, 1383, 1308, 1265 $\mathrm{cm}^{-1}$; ${ }^{1} \mathrm{H}$ NMR $\left(300 \mathrm{MHz}, \mathrm{CDCl}_{3}\right) \square=0.72(1 \mathrm{H}, \mathrm{t}, J=13.2 \mathrm{~Hz}), 0.85(3 \mathrm{H}, \mathrm{d}, J=7.0 \mathrm{~Hz}), 0.87$ $(3 \mathrm{H}, \mathrm{d}, J=7.0 \mathrm{~Hz}), 0.90(3 \mathrm{H}, \mathrm{d}, J=6.3 \mathrm{~Hz}), 1.17(1 \mathrm{H}, \mathrm{ddd}, J=1.9,4.1,12.4 \mathrm{~Hz}), 1.54-1.76(3 \mathrm{H}$, m), 1.29-1.53 (4H, m), $2.39(1 \mathrm{H}, \mathrm{dsept}, J=1.6,7.1 \mathrm{~Hz}), 2.44(1 \mathrm{H}, \mathrm{ddd}, J=1.8,4.3,16.1 \mathrm{~Hz})$, $2.56(1 \mathrm{H}, \mathrm{ddd}, J=2.5,8.2,16.1 \mathrm{~Hz}), 2.72(1 \mathrm{H}, \mathrm{ddd}, J=1.9,3.1,13.5 \mathrm{~Hz}), 3.83(1 \mathrm{H}$, ddd, $J=1.3$, $5.2,11.7 \mathrm{~Hz}), 4.13(1 \mathrm{H}$, ddd, $J=2.7,11.7,11.9 \mathrm{~Hz}), 4.36(1 \mathrm{H}$, dddd, $J=2.9,4.3,7.4,8.2 \mathrm{~Hz})$, $9.80(1 \mathrm{H}, \mathrm{dd}, J=1.8,2.5 \mathrm{~Hz}) ;{ }^{13} \mathrm{C}$ NMR $\left(75 \mathrm{MHz}, \mathrm{CDCl}_{3}\right) \square=18.8,21.7,22.2,23.7,24.2,28.9$, 31.1, 34.8, 37.2, 49.9, 51.1, 58.7, 63.8, 100.9, 201.4; HRMS Calcd for $\mathrm{C}_{15} \mathrm{H}_{26} \mathrm{O}_{3}: 254.1882$. Found: $254.1877 ;[\square]_{\mathrm{D}}{ }^{20}=-11.2^{\circ}\left(c 1.28, \mathrm{CHCl}_{3}\right) . \mathbf{1 6} \square: \mathrm{R}_{f}\left(\mathrm{Et}_{2} \mathrm{O} /\right.$ hexanes $\left.2: 8\right)=0.41$; IR (film) 2952, 2869, 2725, 1728, 1456, 1379, 1308, 1245, 1160, 1115, $1008 \mathrm{~cm}-1$; ${ }^{1} \mathrm{H}$ NMR $(300 \mathrm{MHz}$, $\left.\mathrm{CDCl}_{3}\right) \square=0.71(1 \mathrm{H}, \mathrm{t}, J=13.0 \mathrm{~Hz}), 0.86(3 \mathrm{H}, \mathrm{d}, J=6.9 \mathrm{~Hz}), 0.87(3 \mathrm{H}, \mathrm{d}, J=6.9 \mathrm{~Hz}), 0.89(3 \mathrm{H}$, $\mathrm{d}, J=6.0 \mathrm{~Hz}), 1.17(1 \mathrm{H}, \mathrm{ddd}, J=2.4,3.9,12.6 \mathrm{~Hz}), 1.25-1.74(7 \mathrm{H}, \mathrm{m}), 2.33(1 \mathrm{H}, \mathrm{dsept}, J=2.4$, $6.9 \mathrm{~Hz}), 2.47(1 \mathrm{H}$, ddd, $J=1.8,5.1,16.2 \mathrm{~Hz}), 2.57(1 \mathrm{H}, \mathrm{ddd}, J=2.4,6.9,16.2 \mathrm{~Hz}), 2.72(1 \mathrm{H}$, ddd, $J=1.5,3.3,13.6 \mathrm{~Hz}), 3.78(1 \mathrm{H}, \mathrm{ddd}, J=1.5,5.4,11.7 \mathrm{~Hz}), 3.90(1 \mathrm{H}, \mathrm{ddd}, J=2.7,12.0$, $12.0 \mathrm{~Hz}), 4.53(1 \mathrm{H}, \mathrm{m}), 9.79(1 \mathrm{H}, \mathrm{dd}, J=1.8,2.4 \mathrm{~Hz}) ;{ }^{13} \mathrm{C} \mathrm{NMR}\left(75 \mathrm{MHz}, \mathrm{CDCl}_{3}\right) \square=18.9,22.2$, 22.3, 23.8, 24.5, 29.0, 31.1, 34.8, 37.3, 50.0, 51.0, 58.4, 63.7, 100.9, 201.5; HRMS Calcd for $\mathrm{C}_{15} \mathrm{H}_{26} \mathrm{O}_{3}: 254.1882$. Found: $254.1871 ;[\square]_{\mathrm{D}}^{20}=-50.5^{\circ}\left(c 0.19, \mathrm{CHCl}_{3}\right)$. 


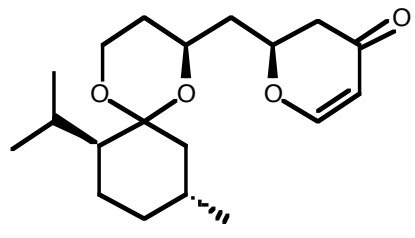

17马

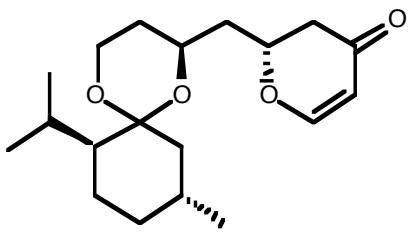

$17 \square$

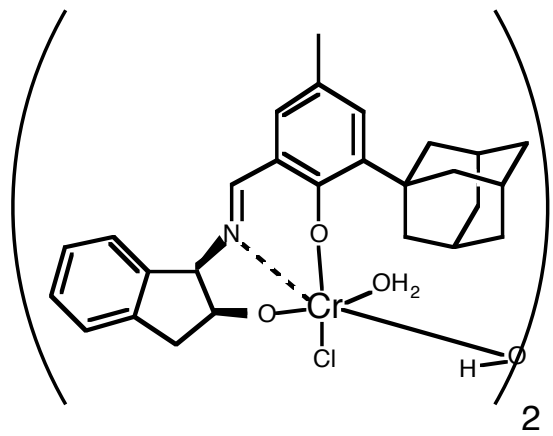

Tridentate Cr ${ }^{\mathrm{III}}$ Catalyst

To an oven dried argon purged flask was added activated powdered $4 \AA$ MS (182 mg), which were cooled to rt under a stream of argon. This was transferred to a solution of 16 (232 $\mathrm{mg}, 0.912 \mathrm{mmol}$ ) dissolved in acetone (182 $\square \mathrm{L}$, freshly distilled from $\mathrm{CaCO}_{3}$ under $\mathrm{N}_{2}$ ) in a $5 \mathrm{~mL}$ oven dried, argon purged flask. To this was added the tridentate $\mathrm{Cr}^{\mathrm{III}}$ catalyst $(47 \mathrm{mg}, 0.093$ mmol) and the mixture was allowed to stir for $3 \mathrm{~h}$ at $\mathrm{rt}$. At this time Danishefsky's Diene (90\%, $252 \square \mathrm{L}, 1.11 \mathrm{mmol}$, Aldrich) was added and the reaction was stirred for $22 \mathrm{~h}$ at $\mathrm{rt}$. To this was added TBME ( $1 \mathrm{~mL}$, HPLC grade, J. T. Baker) and the reaction was cooled to $-78^{\circ} \mathrm{C}$ followed by the dropwise addition of TFA (100 $\square \mathrm{L})$. The reaction was stirred at $-78^{\circ} \mathrm{C}$ for 13 min then quenched with saturated $\mathrm{NaHCO}_{3}(5 \mathrm{~mL})$. The entire mixture was filtered through Celite 521, eluted with $\mathrm{Et}_{2} \mathrm{O}$ and dried over $\mathrm{MgSO}_{4}$. Upon filtration and evaporation the residue was passed through a plug of silica gel, eluting with $30 \% \mathrm{EtOAc/hexanes} \mathrm{to} \mathrm{yield} \mathrm{a} \mathrm{crude} \mathrm{mixture} \mathrm{of} \mathrm{17 \square} \mathrm{and}$

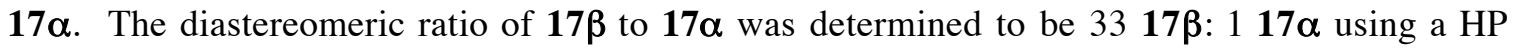
6890 Series GC. The column used to facilitate separation was a HP-5 column and the following method was used for elution: $50^{\circ} \mathrm{C}$ for $0.00 \mathrm{~min}$, ramping to $200^{\circ} \mathrm{C}$ at $10^{\circ} \mathrm{C} / \mathrm{min}$. The oven was kept at $200^{\circ} \mathrm{C}$ for $0.00 \mathrm{~min}$ and then ramped to $230^{\circ} \mathrm{C}$ at $1{ }^{\circ} \mathrm{C} / \mathrm{min}$ where it was kept for $10 \mathrm{~min}$. The retention time for 17 $\square$ was $23.56 \mathrm{~min}$ and the retention time for $17 \square$ was $22.76 \mathrm{~min}$. The crude mixture was then purified by column chromatography, (silica gel, 2:8 EtOAc/hexanes). 17 (260 mg, 88\%) was isolated as a colorless solid. 17 was crystallized by evaporation of a solution in EtOAc/hexanes to yield colorless crystals. 17] was crystallized by evaporation of a solution in EtOAc/hexanes to yield colorless crystals. 17 $\square: \mathrm{R}_{f}($ EtOAc/petroleum ether 15:85) $=$ $0.25 ;{ }^{1} \mathrm{H}$ NMR $\left(300 \mathrm{MHz}, \mathrm{CDCl}_{3}\right) \square=0.70(1 \mathrm{H}, \mathrm{t}, J=12.6 \mathrm{~Hz}), 0.83(3 \mathrm{H}, \mathrm{d}, J=6.9 \mathrm{~Hz}), 0.87$ $(3 \mathrm{H}, \mathrm{d}, J=7.1 \mathrm{~Hz}), 0.88(3 \mathrm{H}, \mathrm{d}, J=6.6 \mathrm{~Hz}), 1.18(1 \mathrm{H}, \mathrm{ddd}, J=1.9,3.9,12.5 \mathrm{~Hz}), 1.28-1.75(8 \mathrm{H}$, m), $1.91(1 \mathrm{H}, \mathrm{ddd}, J=2.3,9.6,14.3 \mathrm{~Hz}), 2.38(1 \mathrm{H}, \mathrm{dsept}, J=1.6,6.9 \mathrm{~Hz}), 2.42-2.56(2 \mathrm{H}, \mathrm{m})$, $2.70(1 \mathrm{H}, \mathrm{ddd}, J=1.9,2.8,13.5 \mathrm{~Hz}), 3.81(1 \mathrm{H}, \mathrm{ddd}, J=1.2,5.2,11.6 \mathrm{~Hz}), 4.03-4.15(2 \mathrm{H}, \mathrm{m})$, $4.67(1 \mathrm{H}$, dddd, $J=3.0,5.8,9.6,11.8 \mathrm{~Hz}), 5.40(1 \mathrm{H}, \mathrm{d}, J=6.0 \mathrm{~Hz}), 7.31(1 \mathrm{H}, \mathrm{d}, J=6.0 \mathrm{~Hz}) ;{ }^{13} \mathrm{C}$ $\operatorname{NMR}\left(75 \mathrm{MHz}, \mathrm{CDCl}_{3}\right) \square=18.9,21.9,22.2$, 23.6, 24.2, 29.0, 31.7, 34.8, 37.3, 41.7, 42.5, 51.1, 58.9, 63.3, 75.7, 100.7, 107.3, 162.9,192.7; Anal. Calcd for $\mathrm{C}_{19} \mathrm{H}_{30} \mathrm{O}_{4}: \mathrm{C}, 70.77 ; \mathrm{H}, 9.38$. Found:

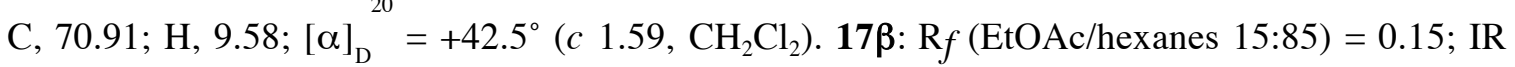
(film) 2952, 2869, 1682, 1597, 1456, 1405, $1269 \mathrm{~cm}^{-1}$; ${ }^{1} \mathrm{H}$ NMR $\left(300 \mathrm{MHz}, \mathrm{CDCl}_{3}\right) \square=0.70$ $(1 \mathrm{H}, \mathrm{t}, J=13.5 \mathrm{~Hz}), 0.86(3 \mathrm{H}, \mathrm{d}, J=6.9 \mathrm{~Hz}), 0.87(3 \mathrm{H}, \mathrm{d}, J=6.9 \mathrm{~Hz}), 0.89(3 \mathrm{H}, \mathrm{d}, J=6.7 \mathrm{~Hz})$, $1.17(1 \mathrm{H}$, ddd, $J=1.9,3.8,12.6 \mathrm{~Hz}), 1.20-1.75(7 \mathrm{H}, \mathrm{m}), 1.79(1 \mathrm{H}$, ddd, $J=4.2,6.9,14.0 \mathrm{~Hz})$, $2.02(1 \mathrm{H}$, ddd, $J=5.6,8.3,14.0 \mathrm{~Hz}), 2.39(1 \mathrm{H}$, dsept, $J=1.6,6.9 \mathrm{~Hz}), 2.47(1 \mathrm{H}$, ddd, $J=0.9$, 4.0, $16.8 \mathrm{~Hz}), 2.63(1 \mathrm{H}, \mathrm{dd}, J=13.3,16.8 \mathrm{~Hz}), 2.67(1 \mathrm{H}, \mathrm{ddd}, J=1.9,3.2,13.5 \mathrm{~Hz}), 3.81(1 \mathrm{H}$, ddd, $J=1.4,5.4,11.6 \mathrm{~Hz}), 4.00(1 \mathrm{H}$, dddd, $J=1.0,4.2,8.3,15.5 \mathrm{~Hz}), 4.09(1 \mathrm{H}$, ddd, $J=2.8$, $11.6,12.0 \mathrm{~Hz}), 4.61(1 \mathrm{H}$, dddd, $J=2.8,11.6,12.0 \mathrm{~Hz}), 5.40(1 \mathrm{H}, \mathrm{dd}, J=0.9,6.0 \mathrm{~Hz}), 7.33(1 \mathrm{H}$, $\mathrm{d}, J=6.0 \mathrm{~Hz}) ;{ }^{13} \mathrm{C} \mathrm{NMR}\left(75 \mathrm{MHz}, \mathrm{CDCl}_{3}\right) \mathrm{\square}=18.8,21.8,22.2,23.7,24.2,29.3,31.4,34.7,37.3$, 
40.9, 41.6, 51.1, 58.8, 63.9, 76.4, 100.7, 107.1, 163.3, 192.6; HRMS Calcd for $\mathrm{C}_{19} \mathrm{H}_{30} \mathrm{O}_{4}$ : 322.2144. Found: $322.2146 ; ;[]_{\mathrm{D}}^{20}=-57.8^{\circ}\left(c 1.5, \mathrm{CH}_{2} \mathrm{Cl}_{2}\right)$.

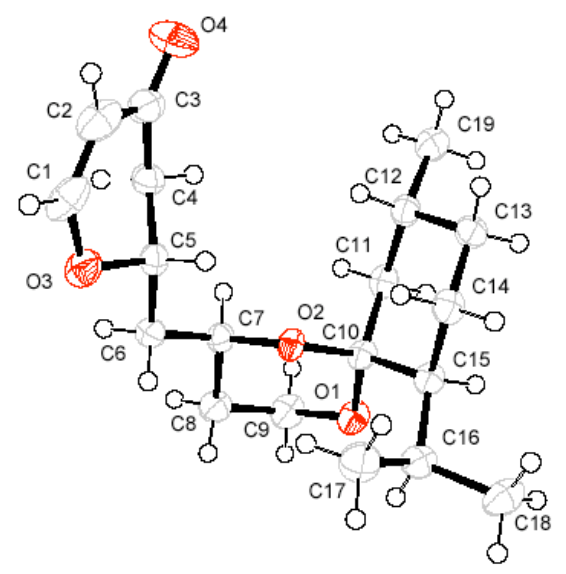

$17 \square$

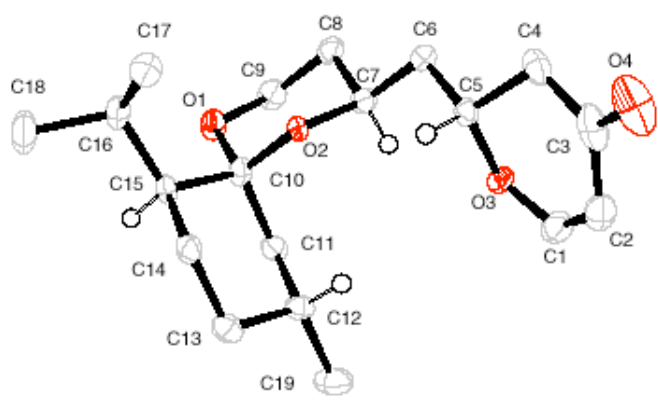

$17 \square$

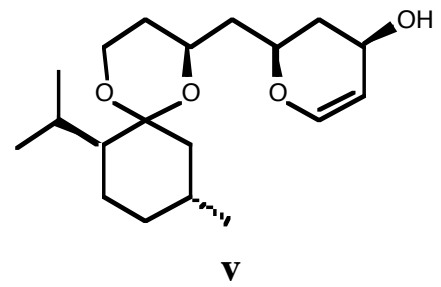

In an oven dried argon purged $250 \mathrm{~mL}$ round bottom flask, charged with a magnetic spin

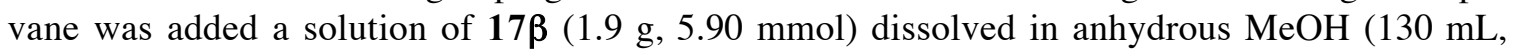
HPLC grade, JT Baker). To this solution was added $\mathrm{CeCl}_{3} \bullet 7 \mathrm{H}_{2} \mathrm{O}(1.32 \mathrm{~g}, 3.54 \mathrm{mmol})$ and the reaction was allowed to stir at $\mathrm{rt}$ for $10 \mathrm{~min}$. It was then cooled to $-50^{\circ} \mathrm{C}$ and $\mathrm{NaBH}_{4}(480 \mathrm{mg}$, $12.69 \mathrm{mmol}$ ) was added in one portion. The reaction was allowed to stir for $30 \mathrm{~min}$ at $-50^{\circ} \mathrm{C}$ and then warmed to rt, at which temperature it was allowed to react for an additional $10 \mathrm{~min}$. The reaction was then quenched with brine $(50 \mathrm{~mL})$. The aqueous layer was extracted with EtOAc (3 x $75 \mathrm{~mL}$ ) and the combined organic washes were dried over $\mathrm{MgSO}_{4}$. After filtration and evaporation the crude material was purified by column chromatography (silica gel, 2:8 EtOAc/hexanes). Single diastereomer $\mathbf{v}(1.76 \mathrm{~g}, 92 \%)$ was isolated as a colorless oil. $\mathbf{v}: \mathbf{R}_{f}$ $($ EtOAc/hexanes 2:8) $=0.19$; IR $($ film) $3386,2951,2869,1643,1456,1380,1307,1268,1231$ $\mathrm{cm}^{-1} ;{ }^{1} \mathrm{H}$ NMR $\left(300 \mathrm{MHz}, \mathrm{CDCl}_{3}\right) \square=0.69(1 \mathrm{H}, \mathrm{t}, J=12.7 \mathrm{~Hz}), 0.88(6 \mathrm{H}, \mathrm{d}, J=6.9 \mathrm{~Hz}), 0.90$ $(3 \mathrm{H}, \mathrm{d}, J=6.2 \mathrm{~Hz}), 1.17(1 \mathrm{H}, \mathrm{ddd}, J=1.9,4.4,12.3 \mathrm{~Hz}), 1.33-1.74(9 \mathrm{H}, \mathrm{m}), 1.90(1 \mathrm{H}, \mathrm{ddd}, J=$ 6.6, 7.7, $14.0 \mathrm{~Hz}), 2.18(1 \mathrm{H}$, dddd, $J=1.7,1.9,6.4,13.0 \mathrm{~Hz}), 2.39(1 \mathrm{H}$, dsept, $J=1.7,6.9 \mathrm{~Hz})$, $2.69(1 \mathrm{H}, b r \mathrm{~d}, J=13.5 \mathrm{~Hz}), 3.81(1 \mathrm{H}, \mathrm{ddd}, J=1.5,5.2,11.5 \mathrm{~Hz}), 3.98(1 \mathrm{H}$, dddd, $J=2.7,5.2$, 7.9, $10.9 \mathrm{~Hz}), 4.08(1 \mathrm{H}, \mathrm{ddd}, J=2.7,12.4,12.4 \mathrm{~Hz}), 4.08-4.17(1 \mathrm{H}, \mathrm{m}), 4.36-4.46(1 \mathrm{H}, \mathrm{m}), 4.75$ $(1 \mathrm{H}, \mathrm{ddd}, J=1.9,1.9,6.1 \mathrm{~Hz}), 6.35(1 \mathrm{H}, b r \mathrm{~d}, J=5.4 \mathrm{~Hz}) ;{ }^{13} \mathrm{C} \mathrm{NMR}\left(75 \mathrm{MHz}, \mathrm{CDCl}_{3}\right) \square=18.8$, 21.8, 22.2, 23.7, 24.2, 29.2, 31.3, 34.9, 37.4, 37.7, 41.5, 51.2, 58.9, 63.0, 64.3, 71.4, 100.6, 105.5, $145.3 ;[\square]_{\mathrm{D}}^{20}=+2.0^{\circ}\left(c 0.59, \mathrm{CHCl}_{3}\right){ }^{4}$

\footnotetext{
${ }^{4}$ Compound's instability prevented the acquisition of reliable HRMS and elemental analysis data.
} 


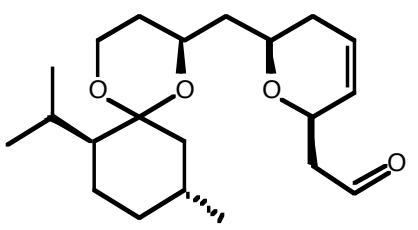

18

In an oven dried argon purged $100 \mathrm{~mL}$ round bottom flask charged with a magnetic stir bar was added a solution of $\mathbf{v}(482 \mathrm{mg}, 1.49 \mathrm{mmol})$ in isobutylvinyl ether $(31 \mathrm{~mL}, 238 \mathrm{mmol})$. $\mathrm{Hg}(\mathrm{OAc})_{2}(237 \mathrm{mg}, 0.744 \mathrm{mmol})$ was added and the reaction was run at $\mathrm{rt}$ for $48 \mathrm{~h}$. The reaction was diluted with EtOAc $(30 \mathrm{~mL})$ and the organic layer was washed with saturated $\mathrm{NaHCO}_{3}(3 \mathrm{x}$ $30 \mathrm{~mL}$ ), followed by brine $(1 \times 30 \mathrm{~mL})$. The organic layer was dried over $\mathrm{MgSO}_{4}$, filtered and concentrated. Rapid column chromatography (silica gel, 15:85 EtOAc/hexanes $+1 \%$ by volume $\mathrm{Et}_{3} \mathrm{~N}$ ) gave the crude enol ether. This was carried on immediately to the next reaction.

In an oven dried argon purged $250 \mathrm{~mL}$ round bottom flask charged with a magnetic stir bar was added a solution of the enol ether $(480 \mathrm{mg}, 1.37 \mathrm{mmol})$ dissolved in anhydrous decane (26 mL, 99\%+, Aldrich). Previous to its use, the decane was degassed by purging it with argon for $1 \mathrm{~h}$ in an oven dried and argon purged $150 \mathrm{~mL}$ round bottom flask. The reaction vessel was lowered into a preheated $155^{\circ} \mathrm{C}$ oil bath and heated for $3 \mathrm{~h}$ at this temperature under an argon atmosphere. It was then removed from the oil bath and cooled to rt. The whole reaction was loaded onto a column using hexanes to assist in the transfer, and purification via column chromatography (silica gel, 1:9 EtOAc/hexanes) yielded $\mathbf{1 8}(431 \mathrm{mg}, 83 \%$ from v) as a colorless oil. 18: $\mathrm{R}_{f}($ EtOAc/hexanes 1:9) $=0.38$; IR (film) 2950, 2869, 1728, 1646, 1456, 1373, 1307, $1267 \mathrm{~cm}^{-1} ;{ }^{1} \mathrm{H}$ NMR $\left(300 \mathrm{MHz}, \mathrm{CDCl}_{3}\right) \square=0.68(1 \mathrm{H}, \mathrm{t}, J=12.9 \mathrm{~Hz}), 0.88(6 \mathrm{H}, \mathrm{d}, J=7.1 \mathrm{~Hz})$, $0.89(3 \mathrm{H}, \mathrm{d}, J=6.6 \mathrm{~Hz}), 1.12-2.14(12 \mathrm{H}, \mathrm{m}), 2.40(1 \mathrm{H}, \mathrm{dsept}, J=1.6,6.9 \mathrm{~Hz}), 2.55(2 \mathrm{H}, \mathrm{dd}, J=$ 2.4, $6.2 \mathrm{~Hz}), 2.69(1 \mathrm{H}, \mathrm{ddd}, J=1.9,3.0,13.4 \mathrm{~Hz}), 3.66-3.82(2 \mathrm{H}, \mathrm{m}), 3.90-4.01(1 \mathrm{H}, \mathrm{m}), 4.08$ $(1 \mathrm{H}, \mathrm{dd} d, \mathrm{~J}=2.7,12.1,12.1 \mathrm{~Hz}), 4.57-4.66(1 \mathrm{H}, m), 5.64(1 \mathrm{H}, \mathrm{dddd}, \mathrm{J}=1.3,1.3,2.5,10.0 \mathrm{~Hz})$, $5.89(1 \mathrm{H}$, dddd, $\mathrm{J}=2.0,2.0,4.7,10.0 \mathrm{~Hz}), 9.78(1 \mathrm{H}, \mathrm{t}, \mathrm{J}=2.4 \mathrm{~Hz}) ;{ }^{13} \mathrm{C} \mathrm{NMR}(75 \mathrm{MHz}, \mathrm{CDCl} 3)$ $=18.9,21.9,22.2,23.7,24.3,29.1,30.7,31.5,34.9,37.4,42.5,48.5,51.2,59.1,64.4,70.5,70.6$, 100.5, 126.3, 128.5, 201.7; HRMS Calcd for $\mathrm{C}_{21} \mathrm{H}_{34} \mathrm{O}_{4}$ : 350.2457. Found: 350.2466 ; [D] $]_{\mathrm{D}}{ }^{27}=0^{\circ}$ (c $1, \mathrm{CH}_{2} \mathrm{Cl}_{2}$ ).

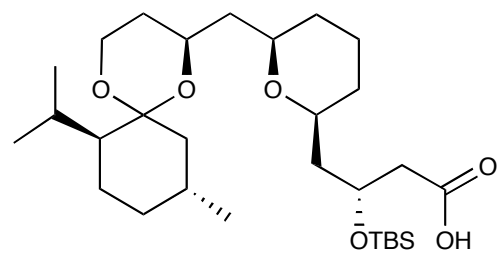

19

In an oven dried, argon purged $200 \mathrm{~mL}$ round bottom flask, charged with a magnetic spin vane was added a solution of 18 (269 $\mathrm{mg}, 0.77 \mathrm{mmol})$ in EtOAc (77 $\mathrm{mL}$, HPLC grade, JT Baker). Pearlman's catalyst $\left(89 \mathrm{mg}, \mathrm{Pd}(\mathrm{OH})_{2} / \mathrm{C} 20 \mathrm{wt} \%, \mathrm{H}_{2} \mathrm{O} \leq 50 \%\right)$ was added and the flask was evacuated under vacuum, then filled with $\mathrm{H}_{2}$ from a balloon. This procedure was repeated three times. The reaction was allowed to stir under $\mathrm{H}_{2}(1 \mathrm{~atm})$ for $30 \mathrm{~min}$. The reaction was filtered through Celite 521, eluting with EtOAc. The filtrate was evaporated and purified by column chromatography (silica gel, 2:8 EtOAc/hexanes) to yield the saturated aldehyde (229 $\mathrm{mg}, 85 \%)$ as a colorless oil which was carried on crude into the next reaction. $\mathrm{R}_{f}($ EtOAc/hexanes 2:8) $=0.24$.

A stock solution of $\mathrm{Ipc}_{2} \mathrm{~B}$ (allyl) was prepared by dissolving (-)-Ipc $\mathrm{I}_{2} \mathrm{BOMe}(5.37 \mathrm{~g}, 17.0$ $\mathrm{mmol})$, weighed into a $100 \mathrm{~mL}$ round bottom oven dried flask in a glove box, in $\mathrm{Et}_{2} \mathrm{O}(43 \mathrm{~mL})$. 
This solution was cooled to $-78^{\circ} \mathrm{C}$ and a $1.0 \mathrm{M}$ solution of allyl magnesium bromide in $\mathrm{Et}_{2} \mathrm{O}$ $(13.9 \mathrm{~mL}, 13.9 \mathrm{mmol})$ was added dropwise. The mixture was warmed to $\mathrm{rt}$ and stirred for $1 \mathrm{~h}$. This was then allowed to stand without stirring for $15 \mathrm{~min}$. In a separate oven dried, argon purged $250 \mathrm{~mL}$ round bottom flask was added a solution of the saturated aldehyde $(815 \mathrm{mg}, 2.31$ $\mathrm{mmol})$ in $\mathrm{Et}_{2} \mathrm{O}(91 \mathrm{~mL})$. To this solution was added an aliquot $(15 \mathrm{~mL})$ of the stock solution of $\mathrm{Ipc}_{2} \mathrm{~B}$ (allyl), dropwise, at $-78^{\circ} \mathrm{C}$. After stirring at $-78^{\circ} \mathrm{C}$ for $2 \mathrm{~h}$, the reaction was treated with $30 \% \mathrm{H}_{2} \mathrm{O}_{2}(2.13 \mathrm{~mL})$ and $3 \mathrm{~N} \mathrm{NaOH}(5.13 \mathrm{~mL})$ and allowed to warm to rt. After stirring at $\mathrm{rt}$ for $2 \mathrm{~h}$, the reaction was diluted with EtOAc $(75 \mathrm{~mL})$ and the organic phase was extracted with brine $(1 \times 100 \mathrm{~mL})$. The aqueous layer was extracted with EtOAc $(3 \times 20 \mathrm{~mL})$ and the combined organic layers were dried over $\mathrm{MgSO}_{4}$. After filtration and evaporation the crude material was cleaned by column chromatography (silica gel, 2:98 EtOAc/hexanes) to yield an inseparable mixture of the homoallylic alcohol and pinan-3-ol. To a solution of this mixture dissolved in $\mathrm{CH}_{2} \mathrm{Cl}_{2}(92 \mathrm{~mL})$ was added TBSCl $(3.48 \mathrm{~g}, 23.1 \mathrm{mmol})$, and imidazole $(3.145 \mathrm{~g}, 46.2 \mathrm{mmol})$ at $\mathrm{rt}$. The reaction was allowed to stir for $16 \mathrm{~h}$. It was quenched by the addition of saturated $\mathrm{NaHCO}_{3}$ $(60 \mathrm{~mL})$. The aqueous layer was extracted with $\mathrm{CH}_{2} \mathrm{Cl}_{2}(3 \times 15 \mathrm{~mL})$ and the combined organic layers were dried over $\mathrm{MgSO}_{4}$, filtered and concentrated. The crude material was purified by column chromatography (silica gel, 2:98 EtOAc/hexanes) to yield the homoallylic TBS ether $(812 \mathrm{mg}, 69 \%$ over two steps $)$ as a colorless oil. $\mathrm{R}_{f}($ EtOAc/hexanes $2: 98)=0.27$.

In an oven dried argon purged $100 \mathrm{~mL}$ round bottom flask charged with a magnetic spin vane was added $\mathrm{NaIO}_{4}(1.00 \mathrm{~g}, 4.69 \mathrm{mmol})$ followed by a pH 7 phosphate buffer $(54 \mathrm{~mL})$. To this solution was added $\mathrm{KMnO}_{4}(93 \mathrm{mg}, 0.586 \mathrm{mmol})$ in one portion. This was allowed to stir for 10 min under an argon atmosphere. This solution was then added to a solution of the homoallylic TBS ether $(298 \mathrm{mg}, 0.586 \mathrm{mmol})$ dissolved in tert-butanol $(54 \mathrm{~mL})$. The reaction was allowed to stir for $90 \mathrm{~min}$ at $\mathrm{rt}$ under an argon atmosphere, maintaining its purple color. The reaction was quenched by the addition of $\mathrm{Na}_{2} \mathrm{~S}_{2} \mathrm{O}_{3}(400 \mathrm{mg}, 1.6 \mathrm{mmol})$ in one portion. The aqueous reaction was extracted with EtOAc ( $3 \times 60 \mathrm{~mL}$ ) and the organic layers were dried over $\mathrm{MgSO}_{4}$. After filtration and evaporation the crude reaction was purified by column chromatography (silica gel, 2:8 EtOAc/hexanes, $+1 \%$ glacial acetic acid) to yield $19(258 \mathrm{mg}, 84 \%)$ as a colorless oil. Glacial acetic acid was removed by azeotroping with heptane. 19: $\mathrm{R}_{f}$ (EtOAc/hexanes 1:4, $+1 \%$ glacial acetic acid $)=0.49$; IR (film) 2933, 1712, 1457, 1255, $1114 \mathrm{~cm}^{-1} ;{ }^{1} \mathrm{H}$ NMR $(400 \mathrm{MHz}$, $\left.\mathrm{CDCl}_{3}\right) \mathrm{C}=0.11(\mathrm{~s}, 3 \mathrm{H}), 0.12(\mathrm{~s}, 3 \mathrm{H}), 0.88(\mathrm{br} \mathrm{s}, 18 \mathrm{H}), 1.85-1.15(\mathrm{~m}, 21 \mathrm{H}), 2.40$ (quint, $J=6.8$ $\mathrm{Hz}, 1 \mathrm{H}), 2.48(\mathrm{dd}, J=15.2,5.2 \mathrm{~Hz}, 1 \mathrm{H}), 2.62(\mathrm{dd}, J=15.2,5.2 \mathrm{~Hz}, 1 \mathrm{H}), 2.69(\mathrm{~d}, J=13.2 \mathrm{~Hz}, 1$ $\mathrm{H}), 3.44(\mathrm{~m}, 2 \mathrm{H}), 3.81(\mathrm{~m}, 1 \mathrm{H}), 3.93(\mathrm{~m}, 1 \mathrm{H}), 4.08(\mathrm{~m}, 1 \mathrm{H}), 4.32(\mathrm{~m}, 1 \mathrm{H}) ;{ }^{13} \mathrm{C}$ NMR $(100$ $\left.\mathrm{MHz}, \mathrm{CDCl}_{3}\right) \square=-4.77,17.92,19.15,21.89,22.25,23.52,23.77,24.31,25.74,29.23,30.93$, $31.89,32.13,37.43,42.48,43.25,43.89$, 43.97, 51.24, 59.14, 64.26, 66.15, 73.52, 73.88, 100.44, 173.48; HRMS Calcd for $\mathrm{C}_{29} \mathrm{H}_{54} \mathrm{O}_{6} \mathrm{Si}$ : 526.3689. Found: 526.3687; [ []$_{\mathrm{D}}^{25}=+22.6^{\circ}(\mathrm{c} 0.58$, $\left.\mathrm{CH}_{2} \mathrm{Cl}_{2}\right)$. 


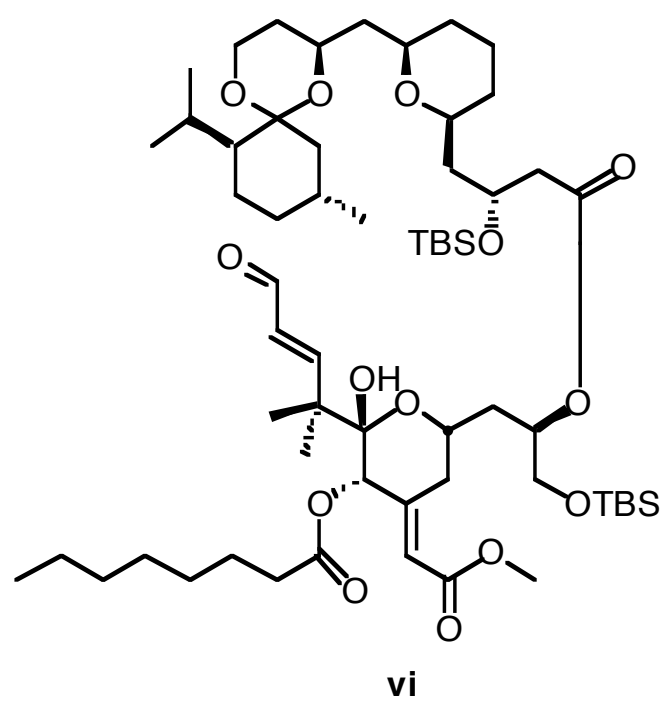

To a solution of acid $19(28 \mathrm{mg}, 0.05 \mathrm{mmol})$ in toluene $(1.1 \mathrm{~mL})$ was added $\mathrm{NEt}_{3}(14 \square \mathrm{L}$, $0.1 \mathrm{mmol})$ and 2,4,6-trichlorobenzoyl chloride $(8 \square \mathrm{L}, 0.05 \mathrm{mmol})$ at $\mathrm{rt}$ and the mixture was stirred for $1 \mathrm{~h}$. To this reaction mixture was added a solution of alcohol $14(15 \mathrm{mg}, 0.025 \mathrm{mmol})$ and DMAP $(15 \mathrm{mg}, 0.125 \mathrm{mmol})$ in toluene $(1.1 \mathrm{~mL})$ at $\mathrm{rt}$. The reaction mixture was stirred for $1 \mathrm{~h}$ and then directly poured onto a column (silica gel, 85:15 hexane:ethyl acetate) and eluted with this solvent system to afford ester vi $(24 \mathrm{mg}, 87 \%)$ as a colorless oil. vi: $\mathrm{R}_{f}$ (hexane/ethyl acetate $85: 15)=0.29$; IR (film) 3492, 2930, 2859, 1725, 1691, 1155, 1112, 837, $777 \mathrm{~cm}^{-1}$; ${ }^{1} \mathrm{H}$ NMR (400 $\left.\mathrm{MHz}, \mathrm{CDCl}_{3}\right) \square=0.04(3 \mathrm{H}, \mathrm{s}), 0.05(3 \mathrm{H}, \mathrm{s}), 0.07(6 \mathrm{H}, \mathrm{s}), 0.68(1 \mathrm{H}, \mathrm{t}, J=13.2 \mathrm{~Hz}), 0.60-0.92$ $(30 \mathrm{H}, \mathrm{m}), 1.10-1.30(18 \mathrm{H}, \mathrm{m}), 1.34-1.84(18 \mathrm{H}, \mathrm{m}), 1.85-2.14(3 \mathrm{H}, \mathrm{m}), 2.34-2.52(3 \mathrm{H}, \mathrm{m}), 2.68$ $(1 \mathrm{H}, \mathrm{d}, J=12.3 \mathrm{~Hz}), 3.13(1 \mathrm{H}, \mathrm{s}), 3.34-3.46(2 \mathrm{H}, \mathrm{m}), 3.60-3.70(3 \mathrm{H}, \mathrm{m}), 3.68(3 \mathrm{H}, \mathrm{s}), 3.76-3.86$ $(2 \mathrm{H}, \mathrm{m}), 3.86-3.96(1 \mathrm{H}, \mathrm{m}), 4.06(1 \mathrm{H}, \mathrm{dt}, J=11.9,2.1 \mathrm{~Hz}), 4.24-4.34(1 \mathrm{H}, \mathrm{m}), 5.11(1 \mathrm{H}, \mathrm{s}), 5.20-$ $5.32(1 \mathrm{H}, \mathrm{m}), 5.96(1 \mathrm{H}, \mathrm{dd}, J=16.1,7.8 \mathrm{~Hz}), 6.00(1 \mathrm{H}, \mathrm{s}), 7.42(1 \mathrm{H}, \mathrm{d}, J=16.1 \mathrm{~Hz}), 9.58(1 \mathrm{H}, \mathrm{d}$, $J=7.8 \mathrm{~Hz}) ;{ }^{13} \mathrm{C}$ NMR $\left(100 \mathrm{MHz}, \mathrm{CDCl}_{3}\right) \square=-5.3,-5.3,-4.7,-4.6,14.0,18.0,18.3,19.2,20.1$, $21.9,22.3,22.5,22.9,23.6,23.7,23.8,24.3,24.5,25.8,28.9,28.9,29.2,30.9,31.0,31.6,31.8$, $31.9,32.0,34.5,35.0,37.4,37.4,43.5,43.8,44.7,45.6,51.2,51.3,59.2,64.4,64.9,65.7,66.3$, $71.1,72.7,73.4,73.8,99.5,100.4,120.5,127.5,150.5,166.4,166.5,171.7,172.1,194.6$; HRMS Calcd for $\mathrm{C}_{60} \mathrm{H}_{106} \mathrm{O}_{14} \mathrm{Si}_{2}\left(\mathrm{M}^{+}\right)$: 1129.7037, Found: $1129.7019 ;[\square]_{\mathrm{D}}^{24.4}=-27.42^{\circ}\left(c 0.87, \mathrm{CH}_{2} \mathrm{Cl}_{2}\right)$.

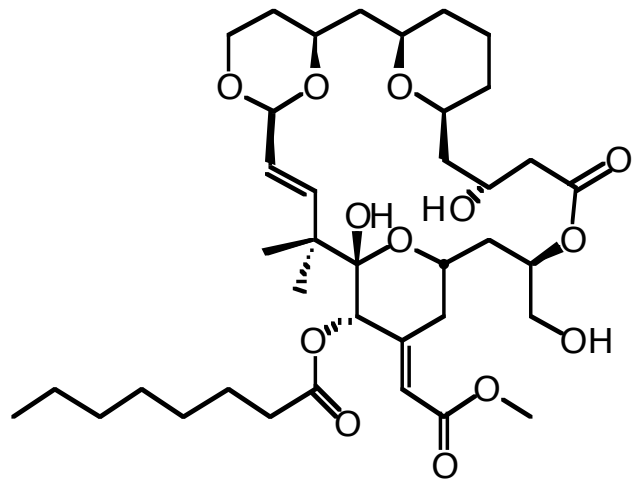


To a solution of ester vi $(20 \mathrm{mg}, 0.02 \mathrm{mmol})$ in THF $(5 \mathrm{~mL})$ at $\mathrm{rt}$ in a plastic vial was added $70 \%$ HF.pyridine ( $970 \square \mathrm{L}, 0.05 \mathrm{mmol}$ ) dropwise and the yellow reaction mixture was stirred for $1.5 \mathrm{~h}$. The reaction was quenched by addition of saturated $\mathrm{NaHCO}_{3}$ solution $(12.5 \mathrm{~mL})$ and $\mathrm{H}_{2} \mathrm{O}(7.5 \mathrm{~mL})$. The biphasic mixture was extracted with EtOAc $(4 \times 12 \mathrm{~mL})$. The combined organic phases were dried over $\mathrm{Na}_{2} \mathrm{SO}_{4}$. After filtration and evacuation of solvents the residue was purified by column chromatography (silica gel, 1:4 hexane:EtOAc) to picolog 1 (11 mg, 82\%) as a white solid. 1: $\mathrm{R}_{f}$ (hexane/ethyl acetate 1:4) $=0.29$; IR (film) 3454, 3332, 2932, 2858, $1723,1663,1138,976, \mathrm{~cm}^{-1} ;{ }^{1} \mathrm{H}$ NMR $\left(400 \mathrm{MHz}, \mathrm{CDCl}_{3}\right) \square=0.86(3 \mathrm{H}, \mathrm{t}, J=6.7 \mathrm{~Hz}), 1.01(3 \mathrm{H}$, s), $1.17(3 \mathrm{H}, \mathrm{s}), 1.18-1.38(12 \mathrm{H}, \mathrm{m}), 1.40-1.66(7 \mathrm{H}, \mathrm{m}), 1.72-1.88(3 \mathrm{H}, \mathrm{m}), 1.94-2.14(3 \mathrm{H}, \mathrm{m})$, $2.29(1 \mathrm{H}, \mathrm{dt}, J=7.5 / 1.7 \mathrm{~Hz}), 2.52(1 \mathrm{H}, \mathrm{d}, J=7.2 \mathrm{~Hz}), 3.45(1 \mathrm{H}, \mathrm{t}, J=11.2 \mathrm{~Hz}), 3.53(1 \mathrm{H}, \mathrm{t}, J=$ $10.6 \mathrm{~Hz}), 3.61-3.72(4 \mathrm{H}, \mathrm{m}), 3.68(3 \mathrm{H}, \mathrm{s}), 3.88(3 \mathrm{H}, \mathrm{t}, J=12.4 \mathrm{~Hz}), 4.02-4.09(2 \mathrm{H}, \mathrm{m}), 4.10-4.19$ $(1 \mathrm{H}, \mathrm{m}), 4.48(1 \mathrm{H}, \mathrm{d}, J=11.6 \mathrm{~Hz}), 5.02(1 \mathrm{H}, \mathrm{d}, J=7.6 \mathrm{~Hz}), 5.10(1 \mathrm{H}, \mathrm{s}), 5.13(1 \mathrm{H}, \mathrm{s}), 5.34-5.39$ $(1 \mathrm{H}, \mathrm{m}), 5.40(1 \mathrm{H}, \mathrm{dd}, J=15.0 / 7.6 \mathrm{~Hz}), 5.97(1 \mathrm{H}, \mathrm{d}, J=15 \mathrm{~Hz}), 5.99(1 \mathrm{H}, \mathrm{s}) ;{ }^{13} \mathrm{C}$ NMR $(100$ $\left.\mathrm{MHz}, \mathrm{CDCl}_{3}\right) \square=14.1,19.3,22.5,23.0,24.4,24.7,28.9,29.0,31.0,31.3,31.4,31.6,32.4,34.6$, 35.9, 39.9, 42.5, 42.9, 45.1, 51.1, 64.5, 65.8, 66.3, 68.6, 71.6, 74.1, 75.8, 76.0, 78.7, 98.9, 102.4, 119.9, 125.7, 142.6, 151.7, 167.0, 172.1, 172.6; HRMS Calcd for $\mathrm{C}_{38} \mathrm{H}_{60} \mathrm{O}_{13}\left(\mathrm{M}^{+}\right)$: 747.3891, Found: $747.3932 ;[\square]_{\mathrm{D}}^{24.0}=-20.02^{\circ}\left(c 0.70, \mathrm{CH}_{2} \mathrm{Cl}_{2}\right)$.

\section{PKC Binding Assay Protocol}

Filters (Whatman GF-B, $21 \mathrm{~mm}$ dia.) are soaked for 1 hour in a solution containing deionized water $(97 \mathrm{~mL})$, and $10 \%$ polyethyleneamine $(3 \mathrm{~mL})$. An assay buffer solution is prepared by the addition of TRIS (1M, pH 7.4, $1 \mathrm{~mL}), \mathrm{KCl}(1 \mathrm{M}, 2 \mathrm{~mL}), \mathrm{CaCl}_{2}(0.1 \mathrm{M}, 30 \square \mathrm{L})$, bovine serum albumin $(40 \mathrm{mg})$, diluted to $20 \mathrm{~mL}$ with deionized water and stored on ice. Phosphatidyl serine vesicles are prepared by the addition of phosphatidyl serine $(10 \mathrm{mg} / \mathrm{mL}$ in choloroform, $0.4 \mathrm{~mL}$ ) to a glass test tube followed by removal of the chloroform under a stream of nitrogen $(5 \mathrm{~min})$. To this viscous liquid is added a portion of the prepared assay buffer $(4 \mathrm{~mL})$ and the resulting mixture is then transferred to a plastic tube with washing. This tube is then sonicated (Branson Sonifier 250, power $=6,40 \%$ duty cycle) four times for $30 \mathrm{sec}$. with a $30 \mathrm{sec}$. rest in-between sonications. The resulting solution is stored over ice. PKC is prepared by the addition of cooled assay buffer $(10 \mathrm{~mL})$ to PKC $(25 \square \mathrm{L})$ purified from the rat brain by the method of Mochly-Rosen ${ }^{5}$ and then sotred on ice. Stock solutions of compounds are diluted with absolute ethanol in glass in serial fashion.

Each plastic assay incubation tube is made to contain prepared phosphatidyl serine vesicles $(60 \square \mathrm{L})$, prepared PKC solution $(200 \square \mathrm{L})$ and analogue $(0-20 \square \mathrm{L}$ plus EtOH $(20-0 \square \mathrm{L})$ for a total volume of $20 \square \mathrm{L}$ ). Lastly, tritiated PDBu (30 nM, $20 \square \mathrm{L})$ is added to each tube. The assay is carried out using 7-10 analogue concentrations, each in triplicate. Non-specific binding is measured in 1-3 tubes by the substitution of phorbol myristate acetate (PMA) (1 mM, $5 \square \mathrm{L}$ ) and $\mathrm{EtOH}(15 \square \mathrm{L})$ for the analogue / $\mathrm{EtOH}$ combination. The tubes are incubated at $37^{\circ} \mathrm{C}$ for 30 min. and then put on ice for $5 \mathrm{~min}$. Each tube is then filtered separately through a pre-soaked filter disc. The filter is subsequently rinsed with cold $20 \mathrm{mM}$ TRIS buffer $(5 \mathrm{~mL})$ dropwise. The filters are then put in separate scintillation vials and Universol ${ }^{\square}$ scintillation fluid is added (3 $\mathrm{mL}$ ). The filters are immediately counted in a scintillation counter (Beckman LS 6000SC). Counts per minute are averaged among three trials at each concentration.

The data is then plotted using a least square fit algorithm with the Macintosh version of Kaleidagraph ${ }^{\square}$ (Abelbeck Software) and an $\mathrm{IC}_{50}$ (defined as the concentration of analogue required to displace half of the specific PDBu binding to $\mathrm{PKC}$ ) is calculated. The $\mathrm{IC}_{50}$ then

\footnotetext{
${ }^{5}$ Mochly-Rosen, D.; Koshland, Jr., D. E. J. Biol. Chem. 1987, 262, 2291-2297.
} 
allows determination of the $\mathrm{K}_{\mathrm{i}}$ for the analogue from the equation: $\mathrm{K}_{\mathrm{i}}=\mathrm{IC}_{50} /(1+[\mathrm{PDBu}]) / \mathrm{K}_{\mathrm{d}}$ of $\mathrm{PDBu}$ ). The $\mathrm{K}_{\mathrm{d}}$ of $\left[{ }^{3} \mathrm{H}\right]-\mathrm{PDBu}$ is determined under identical conditions to be $1.17 \mathrm{nM}$.

\begin{tabular}{|c|c|c|c|}
\hline \multirow[b]{2}{*}{ Cell Line: 6} & \multirow[b]{2}{*}{1} & \multicolumn{2}{|c|}{$\log \left(G I_{50}\right)$ values (in $M$ ) } \\
\hline & & Bryo 1 & $\underline{2}$ \\
\hline \multicolumn{4}{|l|}{ Leukemia } \\
\hline MOLT-4 & $<-8.0$ & -5.50 & -6.91 \\
\hline $\mathrm{K}-562$ & -7.5 & -5.40 & -7.34 \\
\hline \multicolumn{4}{|l|}{ NSC Lung } \\
\hline $\mathrm{NCl}-\mathrm{H} 460$ & $<-8$ & -5.60 & -7.47 \\
\hline A549/ATCC & -6.62 & -5.20 & -6.49 \\
\hline \multicolumn{4}{|l|}{ Colon } \\
\hline COLO 205 & -7.08 & -5.40 & -6.7 \\
\hline HCC-2998 & -7.54 & -5.30 & -3.5 \\
\hline \multicolumn{4}{|l|}{ CNS } \\
\hline SF-295 & -6.05 & -5.20 & -6.56 \\
\hline \multicolumn{4}{|l|}{ Melanoma } \\
\hline SK-MEL-5 & -6.43 & -5.70 & -5.05 \\
\hline \multicolumn{4}{|l|}{ Ovarian } \\
\hline OVCAR-5 & -5.28 & $>-5$ & $>-4$ \\
\hline \multicolumn{4}{|l|}{ Renal } \\
\hline TK-10 & -7.03 & $>-5$ & -7.22 \\
\hline A498 & -6.38 & $>-5$ & -5.7 \\
\hline \multicolumn{4}{|l|}{ Prostate } \\
\hline PC-3 & -5.6 & -5.30 & -5.55 \\
\hline \multicolumn{4}{|l|}{ Breast } \\
\hline MDA-MB-435 & -7.66 & -5.10 & -7.26 \\
\hline $\begin{array}{l}\text { MDA-MB- } \\
231 / \text { ATCC }\end{array}$ & -5.69 & -5.20 & -5.01 \\
\hline
\end{tabular}

\footnotetext{
${ }^{6}$ Assays performed by NCI.
} 